NATIONAL LABORATORY

\title{
Deployment of CF8C-Plus Cast Stainless Steels
}

\section{September 26, 2013}

Prepared by

Bruce A. Pint

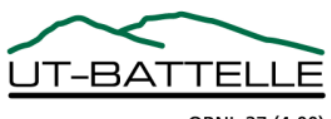




\title{
DOCUMENT AVAILABILITY
}

Reports produced after January 1, 1996, are generally available free via the U.S. Department of Energy (DOE) Information Bridge.

Web site http://www.osti.gov/bridge

Reports produced before January 1, 1996, may be purchased by members of the public from the following source.

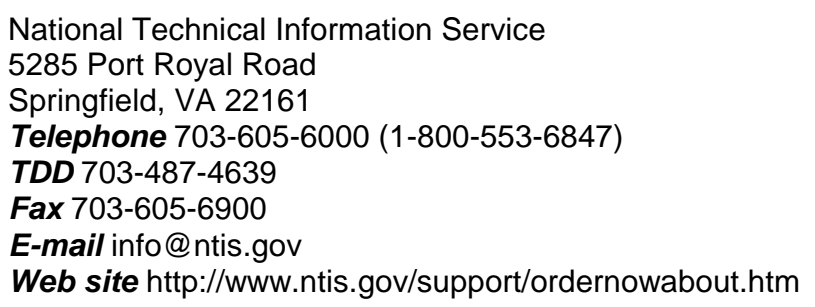

Reports are available to DOE employees, DOE contractors, Energy Technology Data Exchange (ETDE) representatives, and International Nuclear Information System (INIS) representatives from the following source.

Office of Scientific and Technical Information

P.O. Box 62

Oak Ridge, TN 37831

Telephone 865-576-8401

Fax 865-576-5728

E-mail reports@osti.gov

Web site http://www.osti.gov/contact.html

\begin{abstract}
This report was prepared as an account of work sponsored by an agency of the United States Government. Neither the United States Government nor any agency thereof, nor any of their employees, makes any warranty, express or implied, or assumes any legal liability or responsibility for the accuracy, completeness, or usefulness of any information, apparatus, product, or process disclosed, or represents that its use would not infringe privately owned rights. Reference herein to any specific commercial product, process, or service by trade name, trademark, manufacturer, or otherwise, does not necessarily constitute or imply its endorsement, recommendation, or favoring by the United States Government or any agency thereof. The views and opinions of authors expressed herein do not necessarily state or reflect those of the United States Government or any agency thereof.
\end{abstract}


Advanced Manufacturing Office

\title{
DEPLOYMENT OF CF8C-PLUS CAST STAINLESS STEELS Final Report
}

August 31, 2009 to June 30, 2013

\author{
Author \\ Bruce A Pint \\ (865) 576-2897 \\ pintba@ornl.gov \\ Project Team Members \\ Solar Turbines, Inc. \\ Mark D. Lipschutz \\ (619) 544-2373 \\ LIPSCHUTZ_MARK_D@ solarturbines.com \\ Tennessee Technological University, \\ Ying Zhang \\ (931) 239-6812 \\ YZhang@tntech.edu \\ Date Published: September, 2013 \\ Prepared by \\ OAK RIDGE NATIONAL LABORATORY \\ Oak Ridge, Tennessee 37831-6283 \\ managed by \\ UT-BATTELLE, LLC \\ for the \\ U.S. DEPARTMENT OF ENERGY \\ under contract DE-AC05-00OR22725
}





\section{CONTENTS}

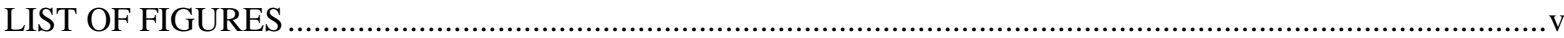

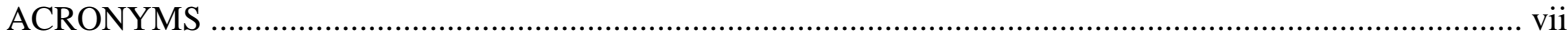

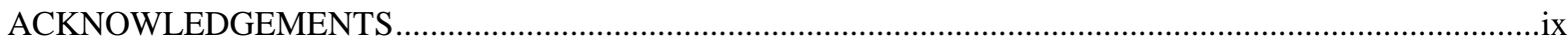

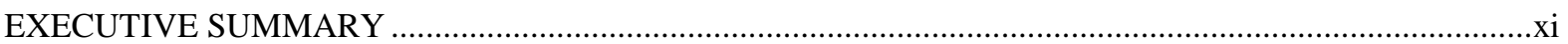

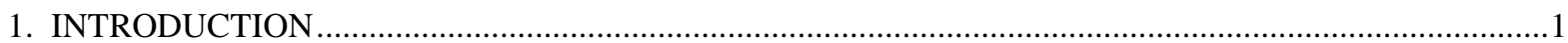

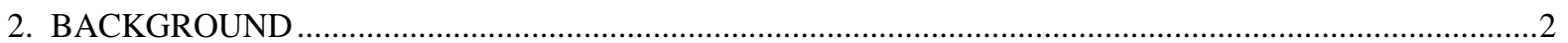

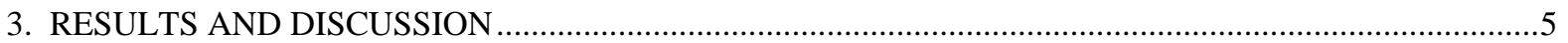

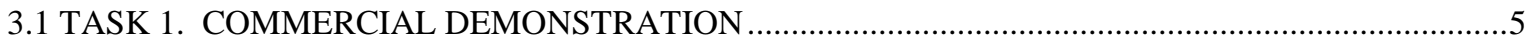

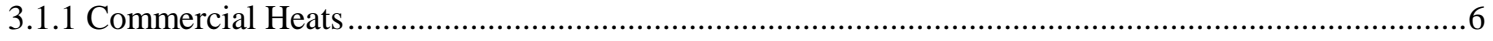

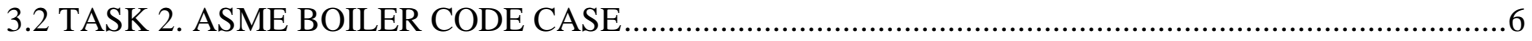

3.3 TASK 3. PROPERTY DATABASE DEVELOPMENT …................................................................

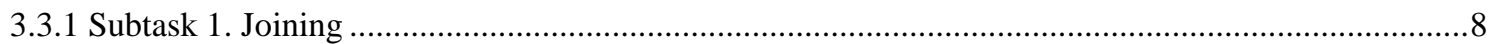

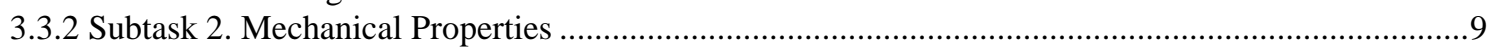

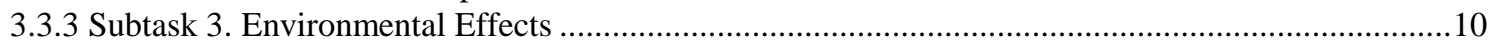

3.4 TASK 4. ALLOY DEVELOPMENT AND OPTIMIZATION ...................................................... 12

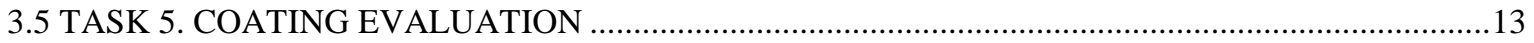

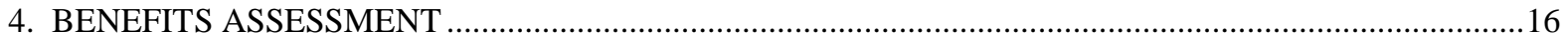

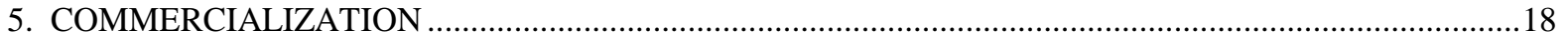

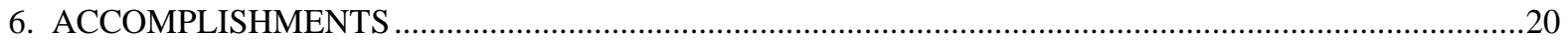

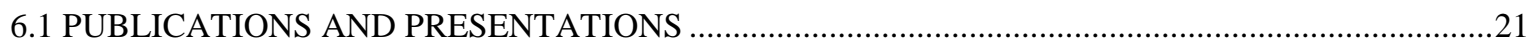

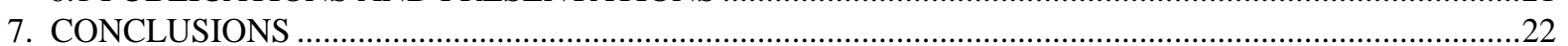

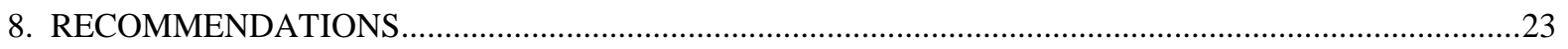

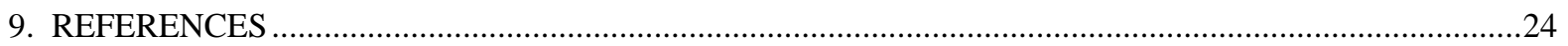





\section{LIST OF FIGURES}

Fig. 1. The Caterpillar Regeneration System (CRS) housing exhaust component using CF8C-Plus cast stainless steel was introduced into production in 2007.

Fig. 2. Larson-Miller Parameter (LMP) plot of the creep rupture data for CF8C-Plus compared to several Ni-

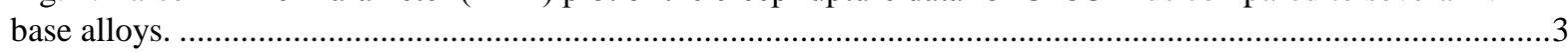

Fig. 3. CF8C-Plus casting of turbine housing at foundry and upon delivery to Solar Turbines...........................5

Fig. 4. Update on the Solar Turbines demonstration at a CHP project in California. The CF8C-Plus housing is

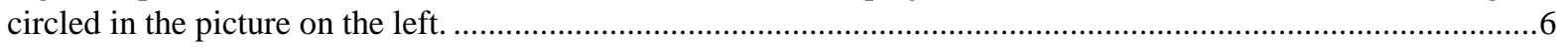

Fig. 5. Keel bars and tube sections from the two commercial orders of CF8C-Plus received in February 2010 ...6

Fig. 6. Tensile data as a function of temperature for the CF8C-Plus code case..........................................

Fig. 7. Larson Miller Parameter (LMP) plot for the CF8C-Plus ASME code case creep data. The black

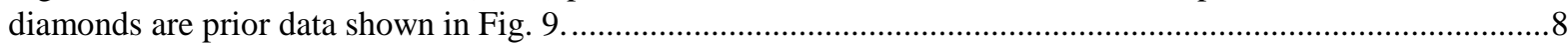

Fig. 8. Gas tungsten arc weld made between two CF8C-Plus plates. .............................................................

Fig. 9. Larson-Miller plot of creep data for CF8C-Plus with and without a gas tungsten arc weld. ....................9

Fig. 10. Cycles to failure in tension compression fatigue as a function of strain range at $600^{\circ}-900^{\circ} \mathrm{C}$...............10

Fig. 11. Comparison of mechanical properties for CF8C-Plus and Cu/W-modified CF8C-Plus (a) Larson-Miller plot of creep data and (b) variation in maximum stress with number of fatigue cycles with $0.5 \%$ strain. ...........10 Fig. 12. Mass change data for the base alloy (CF8C) and modified alloys (with and without $\mathrm{W}$ and $\mathrm{Cu}$ additions) after exposure in several different conditions.

Fig. 13. Light microscopy of polished sections of CF8C-Plus exposed for 1,000h (10, 100-h cycles) at (a) $650^{\circ} \mathrm{C}$, (b) $700^{\circ} \mathrm{C}$ and (c) $800^{\circ} \mathrm{C}$

Fig. 14. Creep-rupture life of $\mathrm{CF} 8 \mathrm{C}$-Plus compared to the $\mathrm{Cu} / \mathrm{W}$ enhanced alloys at $800^{\circ} \mathrm{C}-850^{\circ} \mathrm{C} \ldots \ldots \ldots \ldots \ldots . . . . . .12$

Fig. 15. Specimen mass changes in wet air comparing the CF8C-Plus, to the new alloys $\mathrm{Cu} / \mathrm{W}$ modified $(\mathrm{CF} 8 \mathrm{CW})$ and $\mathrm{Cu} / \mathrm{W}$ modifications with higher $\mathrm{Cr}$ and $\mathrm{Ni}$ contents at $800^{\circ} \mathrm{C}$............................................13

Fig. 16. Specimen mass gain for (a) uncoated and (b) coated CF8C-Plus using several coating methods. .........13

Fig. 17. SEM back-scattered electron images comparing as-fabricated aluminide coatings on CF8C-Plus after 6h at $900^{\circ} \mathrm{C}$ : (left) CVD coating and (right) ORNL slurry coating.

Fig. 18. (a) Variation in maximum stress with number of fatigue cycles for the bare, annealed $900^{\circ} \mathrm{C} / 0.5 \mathrm{~h}$, and slurry coated (annealed $900^{\circ} \mathrm{C} / 0.5 \mathrm{~h}$ ) CF8C-Plus. $\mathrm{N}_{\mathrm{i}}$ represents the number of cycles required to initiate a macrocrack in the sample. (b) Comparison between the number of fatigue cycles to failure $\left(\mathrm{N}_{\mathrm{f}}\right)$ of uncoated and

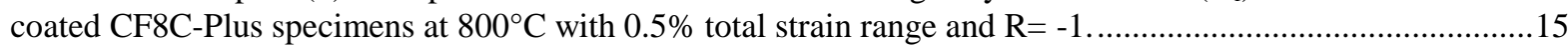

Fig. 19. Estimated total cumulative life energy savings of CF8C-Plus in the automotive market .......................17

Fig. 20. Estimated cumulative material use energy savings due to CF8C-Plus use in the turbine market. ...........17 



\section{ACRONYMS}

AFA

AMO

API

ARRA

ASME

ASTM

BPV

CHP

CRS

CVD

DOE

DPF

EERE

EPRI

$\mathrm{h}$

kh

LCF

LMP

$\mathrm{MPa}$

MW

ORNL

SF\&E

TTU

US
Alumina-forming Austenitic

Advanced Manufacturing Office

American Petroleum Institute

American Recovery and Reinvestment Act

American Society of Mechanical Engineers

American Standards for Testing Materials

Boiler and Pressure Vessel

Combined Heat and Power

Caterpillar Regeneration System

Chemical Vapor Deposition

Department of Energy

Diesel Particulate Filter

Office of Energy Efficiency and Renewable Energy

Electric Power Research Institute

Hours

Thousand hours

Low Cycle Fatigue

Larson Miller Plot

Megapascal

Megawatt

Oak Ridge National Laboratory

Stainless Foundry \& Engineering

Tennessee Technological University

United States 


\section{ACKNOWLEDGEMENTS}

This report is based upon work supported by the Advanced Manufacturing Office (AMO) of the U. S. Department of Energy (DOE) under CPS Agreement 20911 via the Advanced Materials R\&D in Support of EERE Needs to Advance Clean Energy Technologies Program of the American Recovery and Reinvestment Act (ARRA) of 2009. 


\section{EXECUTIVE SUMMARY}

The goal of this project was to accelerate the deployment of a new cast austenitic stainless steel, CF8CPlus, for new energy-relevant applications. The alloy was jointly developed by Oak Ridge National Laboratory (ORNL) and Caterpillar and is a low-cost, high-performance alternative to conventional cast steels and, in some cases, a cost-effective substitute for Ni-base alloys. CF8C-Plus steel won a 2003 R\&D 100 Award, was patented in 2006 and was recognized as a new heat-resistant cast alloy grade by ASTM (HG10MNN). In 2006, CF8C-Plus was successfully commercialized for the Caterpillar Regeneration System (CRS) burner housing, which is needed for the operation of the ceramic diesel particular filter required in all on-highway diesel engines. To date, over 500 tons of CF8C-Plus have been cast for this single application. It was anticipated that the demonstrated commercial success in the CRS application could be translated to an expanded range of other transportation and power generation applications. Increased deployment of CF8C-Plus and $\mathrm{Cu} / \mathrm{W}$ modified CF8C-Plus castings can lead to engines with increased efficiency and durability while lowering cost. Potential industrial partners that were targeted included automotive and diesel engine and part manufacturers as well as turbine, reciprocating engine and boiler manufacturers.

In order to assist in deployment of this new alloy, four research tasks were defined and a solicitation was released to award cost-shared funding to industrial partners. The four research tasks were (1) initiate an ASME boiler and pressure vessel (BPV) code case for CF8C-Plus, (2) increase the public database on CF8C-Plus and modified compositions, (3) explore new alloy development with improved oxidation resistance and (4) investigate the performance of commercial oxidation resistant coatings to increase the maximum operating temperature of CF8C-Plus without affecting the excellent alloy mechanical properties. Code approval is required for CF8C-Plus to be adopted in many fossil energy pump and valve applications.

Solar Turbines Inc. was selected as an industrial partner and their project was to demonstrate CF8CPlus as a turbine housing for the Mercury 50 4.6MW gas turbine engine. The engine was sited at a US. Marine Base in 29 Palms, California as part of an expansion of a successful combined heat and power (CHP) facility. Due to unrelated issues with the expansion work, the startup was delayed and is expected to begin operation in late 2013. While other industrial partners showed interest in the deployment, agreement could not be reached under the required terms.

The project was successful in starting an ASME BPV code case for CF8C-Plus and over 125,000h of creep testing has been completed of the $\sim 400,000 \mathrm{~h}$ of creep testing needed to complete the code case for $1500^{\circ} \mathrm{F}\left(816^{\circ} \mathrm{C}\right)$ operation. With 24 creep frames now operating and follow on funding from the DOE Office of Fossil Energy, the creep testing on three commercial heats and welded material should be completed in $\sim 2$ years. Creep data at $600-700^{\circ} \mathrm{C}$ was better than expected, which helps both the code case applications and gas-turbine housing applications. The database work explored environmental, welding, creep and fatigue work that was published in a number of journal and conference proceeding papers. The alloy development work explored higher $\mathrm{Cr}$ and $\mathrm{Ni}$ contents to improve high temperature oxidation resistance. The study showed the tradeoff between creep and environmental resistance. The coating study also highlighted some of the issues in using coatings on high performance alloys by performing creep and fatigue tests on coated CF8C-Plus.

The deployment of CF8C-Plus in a commercial gas turbine should highlight the use of this alloy in gas turbine and other energy-related applications. Currently several different opportunities appear feasible for exhaust components in diesel and gasoline engines, including turbocharger housings. Furthermore, the eventual completion of the ASME BPV code case will open a variety of new applications for this 
material and provide a validated dataset for system designers. The good creep properties of cast CF8C-Plus have provided interest in properties of wrought CF8C-Plus for main steam line piping in advanced coal-fired power generation. 



\section{INTRODUCTION}

The goal of this project was to accelerate the deployment of a new cast austenitic stainless steel, CF8CPlus, for new energy-relevant applications. The alloy was jointly developed by ORNL and Caterpillar and is a low-cost, high performance alternative to conventional cast steels and, in some cases, a cost effective substitute for Ni-base alloys. Increased deployment of CF8C-Plus and modified CF8C-Plus castings can lead to engines with increased efficiency and durability while lowering cost. Potential end users included automotive and diesel engine and part manufacturers as well as turbine, reciprocating engine and boiler manufacturers. A comprehensive database of material properties for conventional and modified CF8C-Plus, leading to a boiler and pressure vessel code case, is needed to expand the commercial adoption of this material for high temperature applications. Job creation is anticipated due to increased competitiveness of U.S. engine companies and parts manufacturers. 


\section{BACKGROUND}

The Oak Ridge National Laboratory (ORNL) and Caterpillar developed a new cast austenitic stainless steel, CF8C-Plus, which won a 2003 R\&D Award ${ }^{1}$, and was commercialized in $2006^{2,3}$. A U.S. Patent was obtained for CF8C-Plus steel at the end of $2006^{4}$, and an ASTM new alloy grade (HG10MNN) was obtained late in 2008. The first commercial application of CF8C-Plus cast stainless steel was for the Caterpillar Regeneration System (CRS) in late 2006. To meet new regulations on reduced particulates in diesel exhaust in January 2007, all on-highway diesel engines were required to have ceramic diesel particulate filters (DPF). CF8C-Plus steel was chosen as the material for the CRS, which is a burner chamber upstream from the DPF and attached to the turbocharger, Figure 1. Diesel fuel is injected into the exhaust gas, which then triggers pyrolysis of the carbon particles to regenerate the DPF. The CRS unit experiences rapid and severe thermal cycling, with maximum temperatures of $900^{\circ} \mathrm{C}$ or above. To date, over 500 tons of CF8C-Plus have been produced for this single application alone ( 35,000 parts), and no CRS failures have been reported.

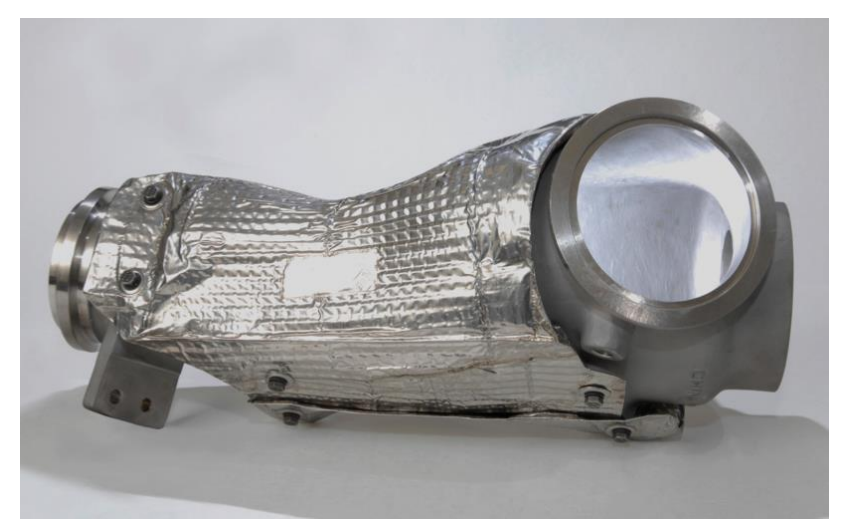

Fig. 1. The Caterpillar Regeneration System (CRS) housing exhaust component using CF8CPlus cast stainless steel was introduced into production in 2007.

CF8C-Plus cast austenitic stainless steel is a fully-austenitic alloy created by adding $\mathrm{Mn}$ and $\mathrm{N}$ to the standard CF8C steel grade (Table 1). The Mn addition improves castability, as well as increasing the alloy solubility for $\mathrm{N}$, and both $\mathrm{Mn}$ and $\mathrm{N}$ act synergistically to boost mechanical properties ${ }^{5-8}$. During high-temperature aging or service at $600^{\circ}-900^{\circ} \mathrm{C}$, CF8C-Plus steel precipitates a fine dispersion of $\mathrm{Nb}-$ rich nano-carbides and nano-nitrides, which strengthen the alloy, but very little of the intermetallic phases, such as sigma, chi or Laves, which can embrittle the material at higher and lower temperatures. CF8C-Plus steel can be air-cast and has its best mechanical properties in the as-cast condition, and does not require any additional heat-treatments. It also has excellent weldability.

CF8C-Plus has mainly been considered for diesel engine exhaust component applications, and as a replacement/upgrade to SiMo ductile cast iron or Ni-resist austenitic cast iron (Table 1), although recently it is being tested for turbocharger housing applications ${ }^{3}$. The superior creep rupture behavior of CF8C-Plus relative to other candidates is shown in Section 3.3.2 (Figure 9a). High temperature components can be made from standard cast stainless steels such as grades CF8C, CF3M or CF10M, which correspond to the wrought grades $347,316 \mathrm{~L}$ and $316 \mathrm{H}$, respectively. Gas-turbines for aeroengine applications have combustors and other hot-gas components made from cast or wrought $\mathrm{Ni}$ based superalloys like X, 617 or 230, and such alloys also are used or considered for microturbine housings or various balance-of-plant components in solid-oxide fuel cell systems. Comparison of the 
creep rupture behavior of CF8C-Plus with wrought or cast versions of alloys $\mathrm{X}, 625,617$ and 230 is shown in Figure 2.

Table 1. Alloy chemical compositions (weight \%)

$\begin{array}{llllllllll} & \text { Fe } & \text { Cr } & \text { Ni } & \text { Mn } & \text { Mo } & \text { Nb } & \text { Si } & \text { C } & \text { Other } \\ \text { Alloy Cast } & & & & & & & & & \\ \text { CF8C } & \text { Bal. } & 19.0 & 10.0 & 0.7 & 0.3 & 0.8 & 1.2 & 0.07 & \\ \text { CF8C-Plus } & \text { Bal. } & 19.0 & 12.5 & 4.0 & 0.3 & 0.8 & 0.5 & 0.10 & 0.25 \mathrm{~N} \\ \text { CF8C+CuW } & \text { Bal. } & 19.0 & 12.5 & 4.0 & 0.3 & 0.8 & 0.5 & 0.10 & \text { 3Cu,1W,.3N } \\ \text { HK30 } & \text { Bal. } & 25 . & 20 & & & & & & \\ \text { HP40Nb } & \text { Bal. } & 24.4 & 35.1 & 1.3 & 0.06 & 1.1 & 1.6 & 0.44 & \\ \text { CF10M } & \text { Bal. } & 20.5 & 10 & 1.0 & 2.4 & & 1.1 & 0.04 & \\ \text { CW6MC } & 3.9 & 21.4 & \text { Bal. } & 0.5 & 8.8 & 3.5 & 0.75 & 0.01 & \\ \text { SiMo } & \text { Bal. } & & & 0.3 & 0.6 & & 4.0 & 3.45 & \\ \text { Ni-Resist } & \text { Bal. } & 2.3 & 34.7 & 0.5 & 1.0 & & 2.6 & 1.90 & \\ \text { Alloy Wrought } & & & & & & & & & \\ \text { 347HFGBal. } & 18.6 & 11.8 & 1.5 & 0.2 & 0.8 & 0.4 & 0.09 & 0.05 \mathrm{~N} & \\ \text { X } & 18 & 22.0 & \text { Bal. } & 1.0 & 9.0 & & <1 & 0.1 & 2 \mathrm{Co}, .6 \mathrm{~W} \\ 230 & <3 & 22.0 & \text { Bal. } & 0.7 & 2.0 & & 0.5 & 0.12 & 14 \mathrm{~W} \\ \text { 625 } & <3 & 23.1 & \text { Bal. } & 0.5 & 9 & 3.6 & 0.4 & 0.07 & 1 \mathrm{Co}, .4 \mathrm{Al}, .4 \mathrm{Ti} \\ 617 & 1.5 & 22.0 & \text { Bal. } & 1.0 & 9.0 & & 1.0 & 0.10 & 13 \mathrm{Co}, 1 \mathrm{Al}, 4 \mathrm{Ti}\end{array}$

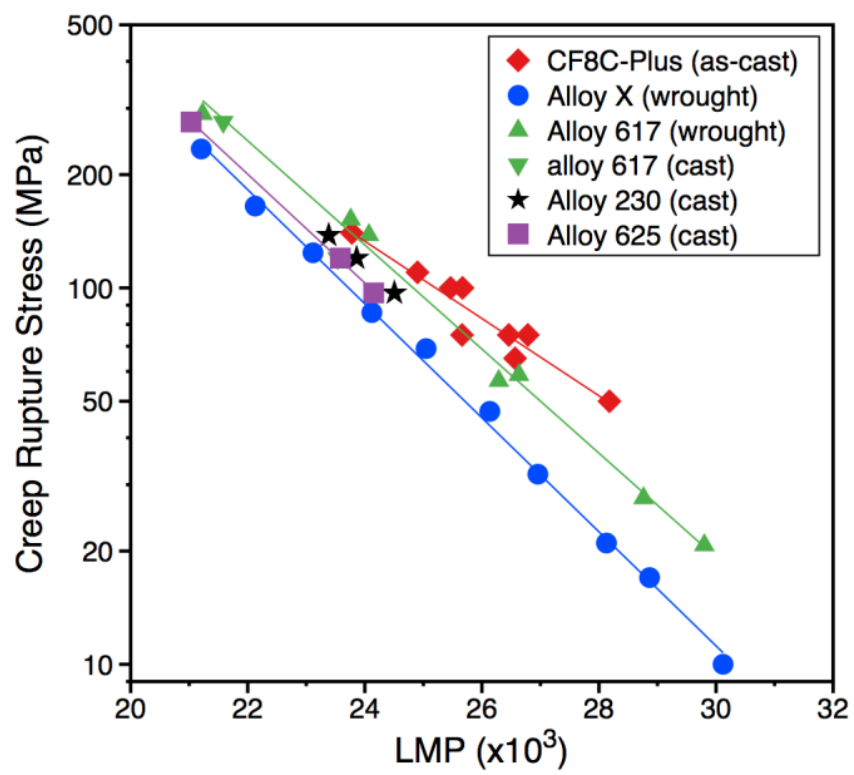

Fig. 2. Larson-Miller Parameter (LMP) plot of the creep rupture data for CF8C-Plus compared to several Ni-base alloys.

While most of the previous data generated and commercial trials have focused on CF8C-Plus steel, another version, modified with $\mathrm{Cu}$ and $\mathrm{W}$ to further enhance creep-resistance at $750^{\circ}-850^{\circ} \mathrm{C}$, is also available (Table 1 and discussed in Sections 3.3 and 3.4). While only a few thousand pounds of CF8CPlus $\mathrm{Cu} / \mathrm{W}$ steel have been melted and data are limited, critical foundry trials indicated this steel also has the same castability and weldability benefits found in the CF8C-Plus steel. Both alloys have similar end users. 


\section{ORNL Research team}

Bruce Pint (PI) has conducted research on high temperature materials for over 25 years and studied materials issues in coal-fired power plants for the past 20 years. He has been involved in several alloy development and commercial deployment projects of ORNL-invented materials. For example, ORNLinvented alumina-forming austenitic (AFA) steel was licensed to Carpenter Technology in March 2011 with several tons of AFA already produced for demonstrations.

Philip Maziasz was the lead inventor for CF8C-Plus. Dr. Maziasz brings 40 years of experience on alloy design and development. The welding work was led by Dr. Michael Santella (now retired) who is a Fellow of the American Welding Society. The code case effort is now led by Dr. Hong Wang and Dr. Sebastien Dryepondt led the environmental resistance evaluation task.

ORNL has a rarely found range of alloy processing, characterization and experimental equipment to readily fabricate and evaluate alloy and weld properties in a short time period.

Solar Turbines, Inc. is a leading industrial gas turbine OEM, offering a range of gas turbines and turbomachinery equipment in the 1-22 MW range for oil \& gas exploration and transmission, and for power generation and cogeneration. Its units operate in 90 countries and account for over 1.4 billion hours of operating service.

Prof. Ying Zhang at Tennessee Technological University has over 15 years of industrial and laboratory experience in coating fabrication and evaluation. 


\section{RESULTS AND DISCUSSION}

This project was organized into five tasks. The first task was commercial demonstrations of CFC8Plus alloys. The objective of task two was to develop creep and tensile data for statically cast CF8C-Plus to support an ASME BPV Code Case that is a requirement for using this alloy in pressure vessel and boiler applications. Task three developed a property database for CF8C-Plus and modified CF8C-Plus steels with subtasks on joining, mechanical properties and environmental effects. Task four was alloy development and optimization by investigating further composition changes to optimize performance. In order to improve the oxidation resistance of CF8C-Plus at temperatures above $700^{\circ} \mathrm{C}, \mathrm{Al}$-rich coatings were evaluated in task 5 with the particular goal of assessing if such coatings will affect the mechanical properties of CF8C-Plus.

\subsection{TASK 1. COMMERCIAL DEMONSTRATION}

In late 2009, an expression of interest was released on FedBizOps to advertise this funding opportunity to all interested parties and several later amendments added. A request for proposals was written and was released by ORNL procurement in November with proposals due in January 2010. One proposal was received from Solar Turbines Inc. in January 2010 and was finalized in August 2010 for a cost shared demonstration of CF8C-Plus as a combustor housing for a 4.6MW Mercury 50 turbine engine. A second partial proposal was received in September 2010 from another industrial partner but, after one year of negotiations, contract terms could not be agreed upon and the proposal was abandoned.

For the Solar Turbines project, two CF8C-Plus housings were fabricated by Wisconsin Centrifugal, Figure 3. The semi-machined weight of each was $\sim 2,620 \mathrm{lbs}$ and both were delivered to Solar Turbines in April 2011. The second casting was cut up for mechanical testing.
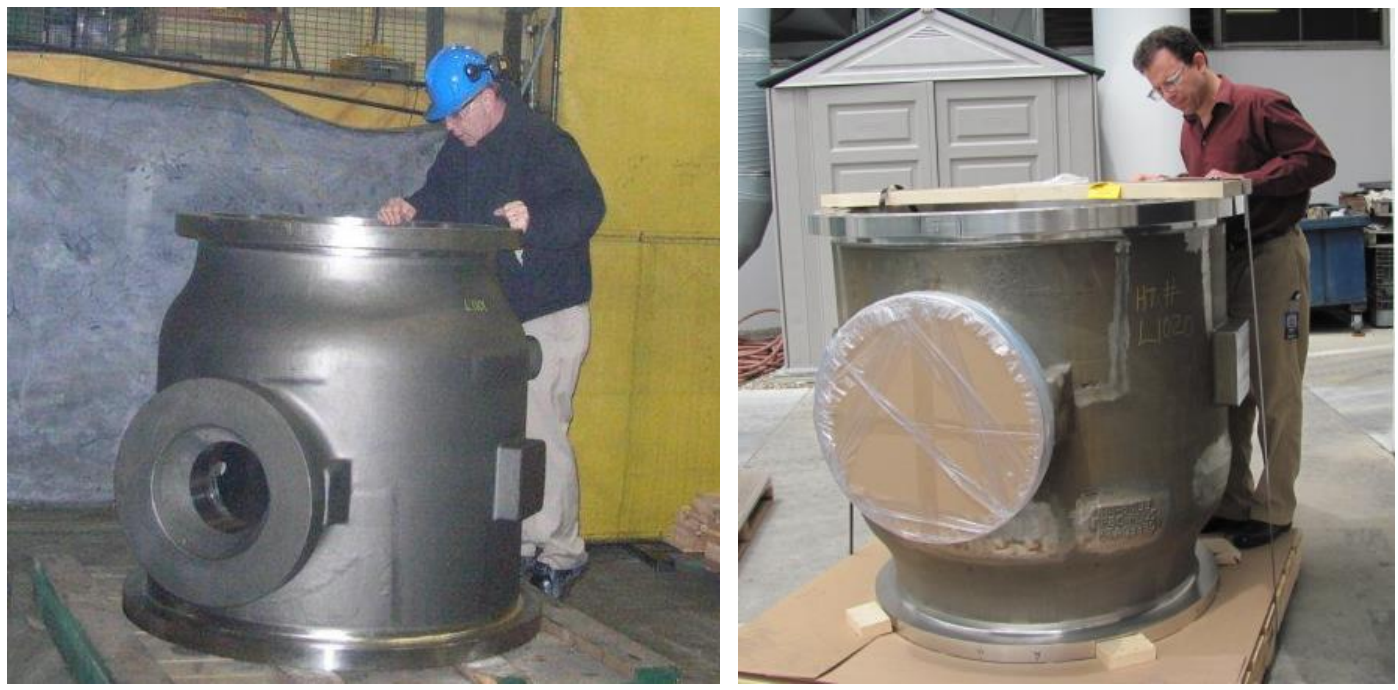

Fig. 3. CF8C-Plus casting of turbine housing at foundry and upon delivery to Solar Turbines.

The Mercury 50 engine with the CF8C-Plus housing was assembled and delivered to the 29 Palms U.S. Marine Corp Base in California for a CHP expansion project in late 2011, Figure 4. After a $\sim 1.5$ year delay in the original project schedule, the CHP project finished hot commissioning in 
April 2013 and commercial operation is expected after July 2013. Tensile, fatigue and creep testing of the material from the $2^{\text {nd }}$ housing was completed in September 2012.

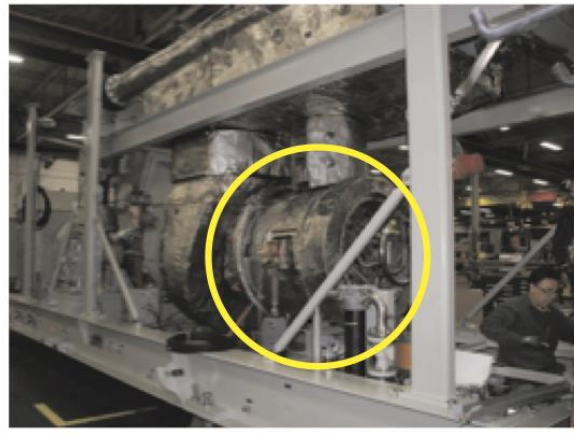

Mercury 50 turbine with CF8C-Plus housing

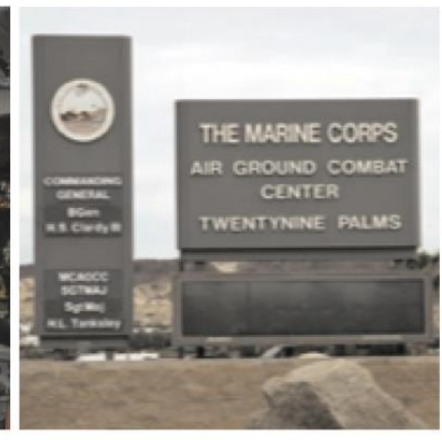

Demonstration site in California

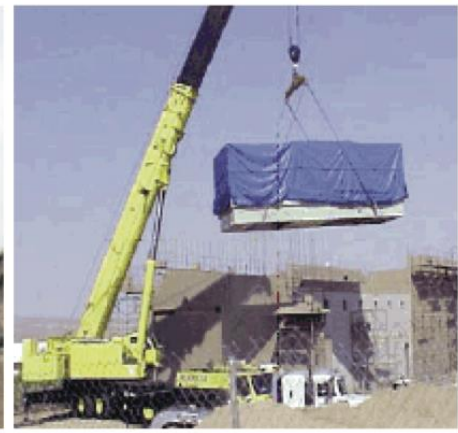

Delivery of Mercury 50 turbine

Fig. 4. Update on the Solar Turbines demonstration at a CHP project in California. The CF8C-Plus housing is circled in the picture on the left.

\subsubsection{Commercial Heats}

In order to assist with the commercial demonstration and the other tasks, three alloy procurements were initiated with two different commercial vendors. Some of the material received in February 2010 is shown in Figure 5. Due to larger sized tensile/creep specimen required for cast alloys, only one specimen could be obtained from each keel bar. The short tubing sections were made to assist with the welding task. A 6' long centrifugally cast tube also was received. One of the first three heats received met specification in the melt stage but not after casting and therefore had to be rejected for the code case. A third procurement in July 2010 replaced this heat.

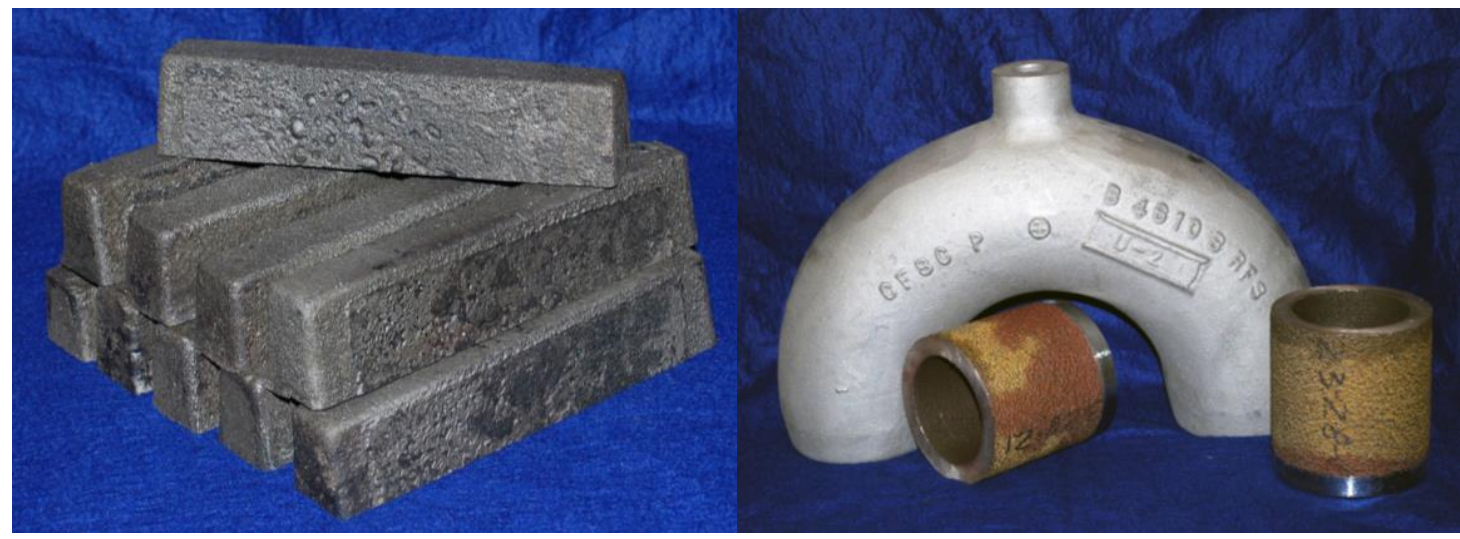

Fig. 5. Keel bars and tube sections from the two commercial orders of CF8C-Plus received in February 2010.

\subsection{TASK 2. ASME BOILER CODE CASE}

The objective of this task was to develop creep and tensile data for statically cast CF8C-Plus to support an ASME BPV Code Case that is a requirement for using this alloy in pressure vessel and boiler applications. Based on an assessment of potential end-users and applications, the ASME B31.3 Process Piping Code for pumps and valves was identified as the construction code for the CF8C-Plus 
application. The testing requirements for B31.3 are the same as the ASME Boiler and Pressure Vessel Code, Sections I and VIII. The initial target maximum application temperature for the Code Case was $650^{\circ} \mathrm{C}\left(1200^{\circ} \mathrm{F}\right)$, which requires testing to $700^{\circ} \mathrm{C}\left(1300^{\circ} \mathrm{F}\right)$ in the data package. After consulting with industrial partners and the Electric Power Research Institute (EPRI), this temperature was increased to $816^{\circ} \mathrm{C}\left(1500^{\circ} \mathrm{F}\right)$ thus requiring testing to $871^{\circ} \mathrm{C}\left(1600^{\circ} \mathrm{F}\right)$ and greatly increasing the work scope for the code case. In addition, the data requirements for a code case were expanded during this same time period, further increasing the minimum required creep testing to over 400,000h. Dr. Robert Swindeman from Cromtech Inc. was hired as a consultant to assist with this task.

Initially 9 creep frames were refurbished for this work. This was expanded to 12 frames in 2010 and to 24 frames in 2012, in order to reduce the time needed to complete the code case to $816^{\circ} \mathrm{C}$. In order to expose the code committees to CF8C-Plus at the earliest possible opportunity, a tensile data package was assembled with stress data to $371^{\circ} \mathrm{C}\left(800^{\circ} \mathrm{F}\right)$, and strength trend curves to $816^{\circ} \mathrm{C}\left(1500^{\circ} \mathrm{F}\right)$, Figure 6. This data was presented to the ASME committee in May 2012. The superior performance of CF8C-Plus is in the time-dependent or creep properties so the time-independent (e.g. tensile) properties do not provide an advantage over other code-qualified alloys.
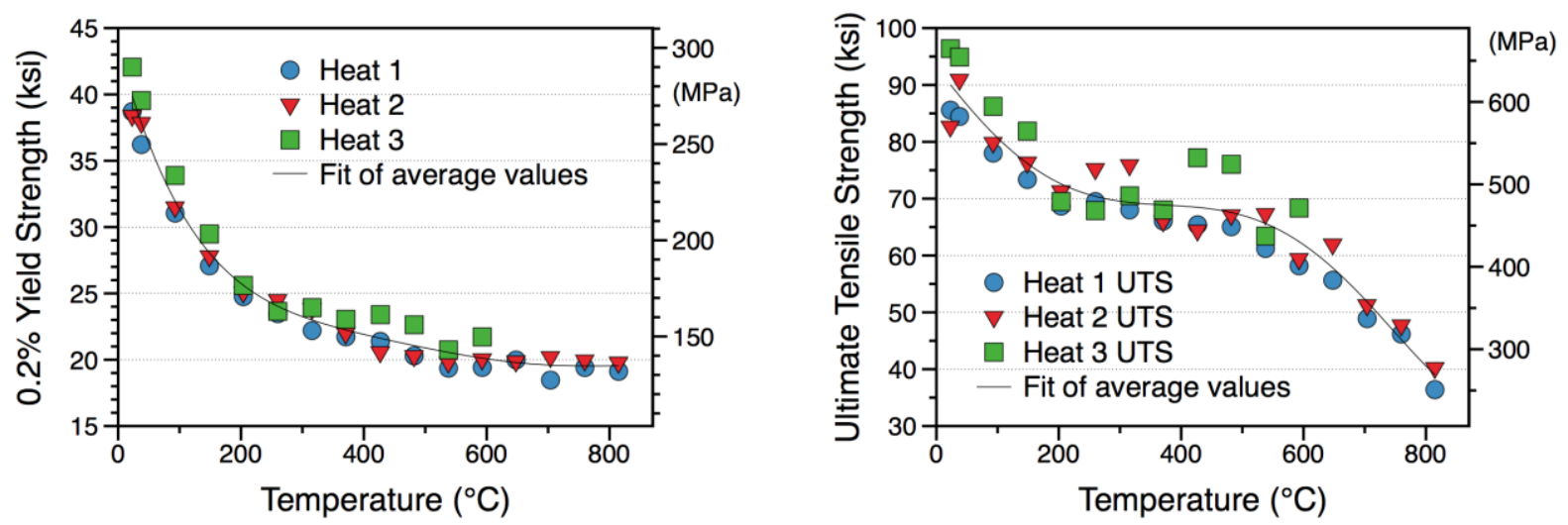

Fig. 6. Tensile data as a function of temperature for the CF8C-Plus code case.

Cromtech collected and evaluated CF8C-Plus data to assemble a preliminary data package suitable for submittal to ASTM for the incorporation of static castings into ASTM Standard Specification A351. In addition, the American Petroleum Institute (API) Recommended Practice 615 (Valve Selection Guide) was reviewed, and it was concluded that CF8C-Plus would be suitable for a number of valve types. Thus, inclusion of CF8C-Plus into Table 1 of ASME B16.34 was targeted.

In November 2012, CF8C-Plus was successfully added to ASTM A297/A297M-10 (Fe-base heat resistant general applications) and A488/A488M-10 (standard practice for steel castings) and ballots are being prepared for A743/A743M-12 (Fe-base corrosion resistant castings) and A351/A351M-12b (pressurized austenitic castings). These will complete the ASTM specification requirements.

Development of weld specimens for the code case was confounded by problems with the weld wire. Two 11/2-inch thick plates of CF8C-Plus were welded by automatic gas-tungsten-arc welding using CF8C Plus filler metal wire produced by the Stoody Company. However, U-bend tests showed cracking and the weld had to be repeated. A second trial weld used sticks of CF8C-Plus but was not large enough to produce mechanical test specimens for the code case. Future work will complete welded specimens using two filler metals and two welding processes for inclusion in the code package. Currently, 24 creep frames are available for the code case creep testing. A summary of the completed and in-progress tests is shown in Figure 7. The new creep rupture lifetimes obtained for the code case 
have exceeded the prior data set. (The dashed line in Figure 7 is a fit of the prior data for CF8C-Plus.) This difference has been attributed to the larger diameter creep specimens recommended for an ASME code case for cast alloys. As a result of the longer creep rupture times, the creep testing has taken longer than expected to complete. The stresses in the test matrix were increased based on these results. However, the significance of the boost in creep-resistance at $550-700^{\circ} \mathrm{C}$ is that $\mathrm{CF} 8 \mathrm{C}$-Plus then compares better with CF8C, $347 \mathrm{H}$ and $\mathrm{CF} 10 \mathrm{M}$, which is beneficial for the turbine housing applications. This is also an advantage for pump and other cast components in chemical and petrochemical applications. In April 2013, funding to continue the code case work for approximately 6 months was obtained from the ORNL Technology Maturation Fund to bridge the work until funding from the DOE Office of Fossil Energy in August 2013. By April 2013, 18 creep tests were in progress and 39 tests had been completed. Testing on two of the heats represented $47 \%$ and $58 \%$ completion of the required test matrix to $871^{\circ} \mathrm{C}$. Most of the remaining tests on these heats are for the highest temperatures that were added later.

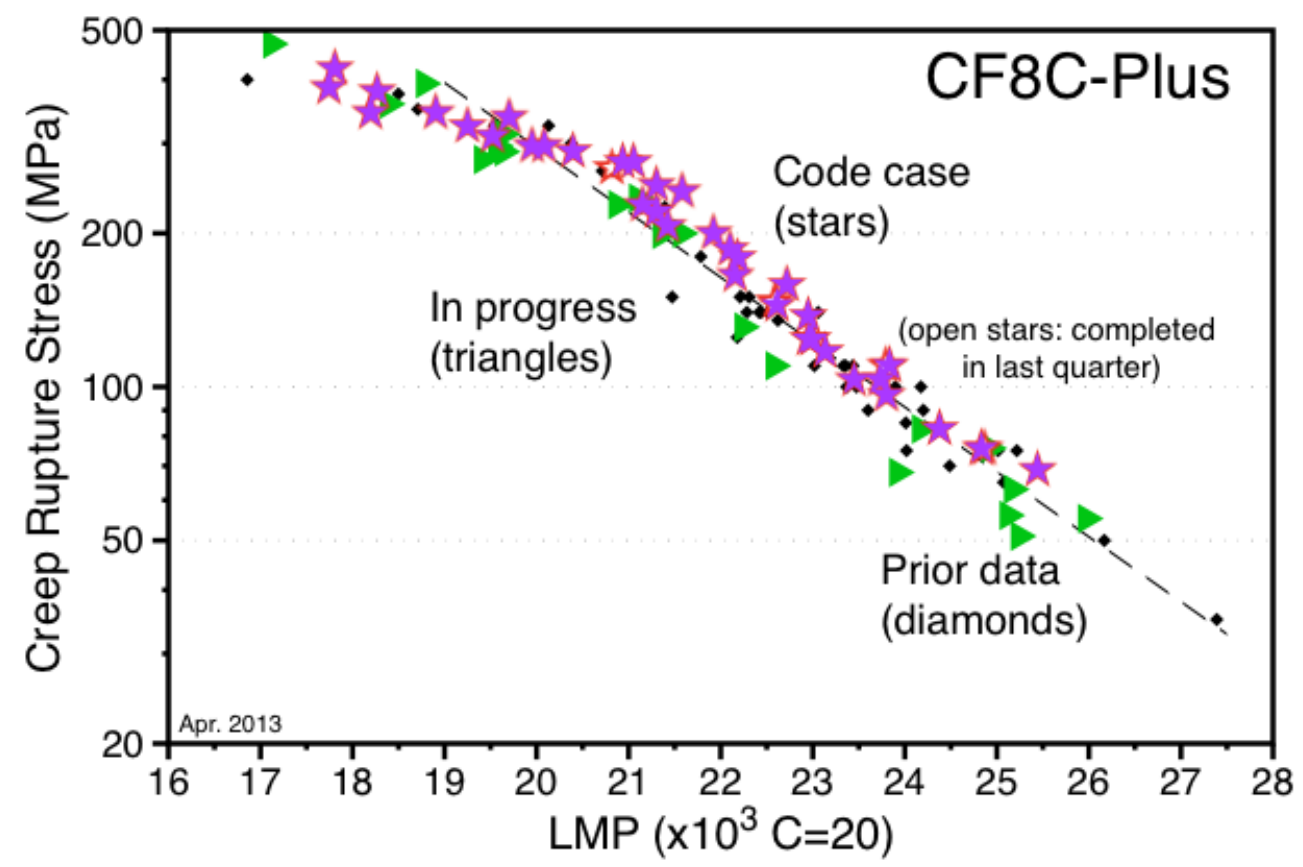

Fig. 7. Larson Miller Parameter (LMP) plot for the CF8C-Plus ASME code case creep data. The black diamonds are prior data shown in Fig. 9.

\subsection{TASK 3. PROPERTY DATABASE DEVELOPMENT}

This task developed a property database for CF8C-Plus and modified CF8C-Plus steels with subtasks on joining, mechanical properties and environmental effects.

\subsubsection{Subtask 1. Joining}

To initiate this work, an agreement was negotiated with a commercial welding products company to produce a trial lot of welding wire having the CF8C-Plus chemical composition. A manual gas tungsten arc weld of two CF8C-Plus $12.5 \mathrm{~mm}$ thick plates was made (Fig. 8) and the weld was radiographed to verify quality and examined by metallography. Creep specimens were cut from the plate with the weld across the specimen gage and creep rupture data is shown in Figure 9. As was shown in limited prior work, there was no debit in creep life due to the weld. Conventional ferritic and 
Ni-base alloys can have 50-75\% weld strength debits. This is a significant advantage for CF8C-Plus in upgrading from ferritic/martensitic steels, and in cost-effective substitution for higher $\mathrm{Ni}$ alloys or $\mathrm{Ni}$ based superalloys. The good behavior of welds of cast CF8C-Plus is also a positive for the applications of wrought CF8C-Plus for main steam line piping in advanced coal-fired power plants ${ }^{9}$.

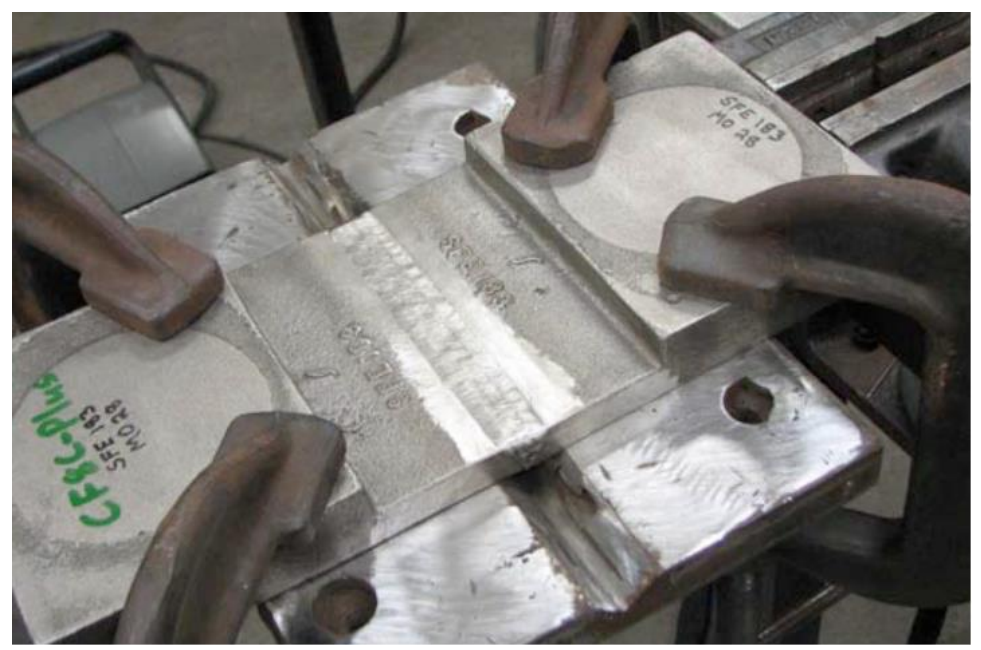

Fig. 8. Gas tungsten arc weld made between two CF8C-Plus plates.

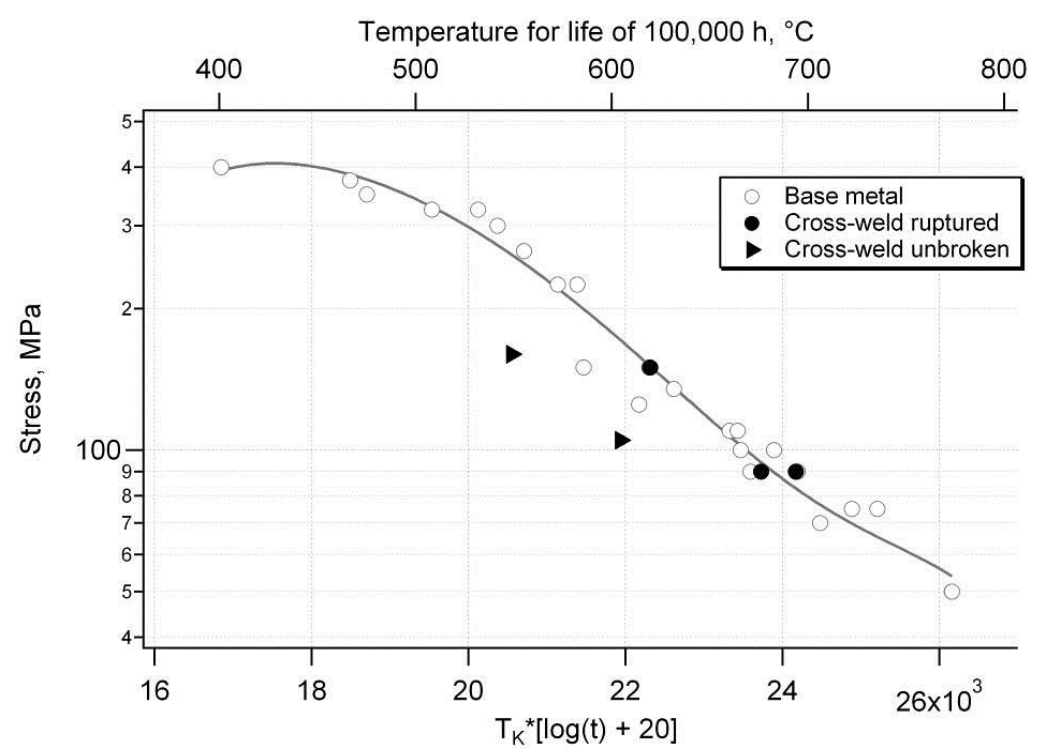

Fig. 9. Larson-Miller plot of creep data for CF8C-Plus with and without a gas tungsten arc weld.

\subsubsection{Subtask 2. Mechanical Properties}

Strain-controlled low cycle fatigue (LCF) tests were performed in air at $600^{\circ}, 800^{\circ}$ and $900^{\circ} \mathrm{C}$ with strain amplitude varying between 0.5 and $2 \%$. A symmetrical triangular waveform and a constant strain rate of $0.05 \% \mathrm{~s}^{-1}$ were employed for all tests. As expected, the alloy fatigue life decreased with temperature, Figure 10. Fracture surfaces and longitudinal cross-sections of the samples fatigued at a $0.5 \%$ strain range showed that the alloy underwent trans-dendritic fracture at $600^{\circ} \mathrm{C}$ and inter-dendritic facture between $800^{\circ} \mathrm{C}$ and $900^{\circ} \mathrm{C}$. 


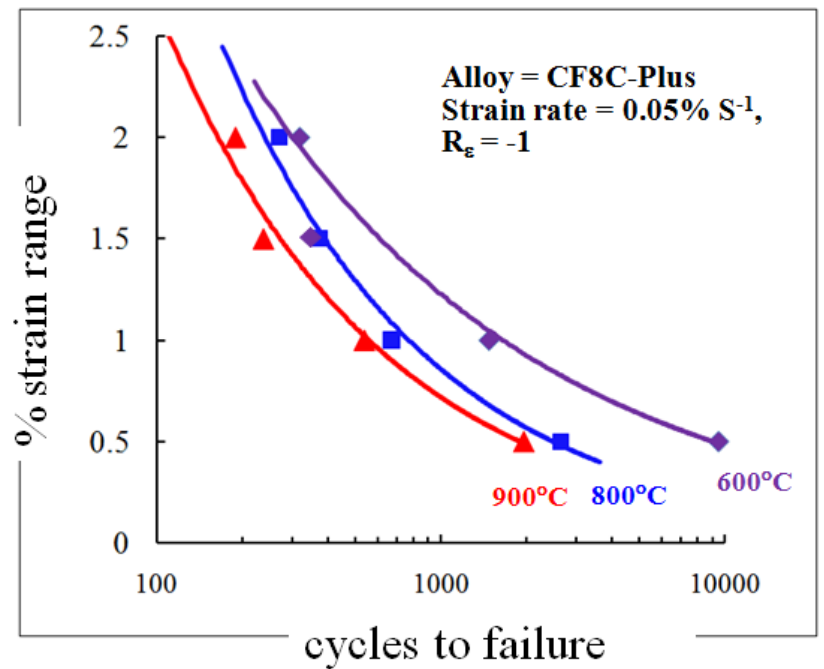

Fig. 10. Cycles to failure in tension compression fatigue as a function of strain range at $600^{\circ}-900^{\circ} \mathrm{C}$.

Figure 11 shows creep and fatigue data for CF8C-Plus with and without $\mathrm{Cu}$ and $\mathrm{W}$ additions. The creep data, some of which is drawn from prior work, shows a longer creep rupture life with the $\mathrm{Cu}$ and $\mathrm{W}$ additions. However, this is generally for higher stresses and temperatures. At lower temperatures and stresses, the lifetimes are similar to the base CF8C-Plus alloy. In fatigue testing at $800^{\circ} \mathrm{C}$, the strain hardening was much higher for the $\mathrm{Cu} / \mathrm{W}$ modified alloy and the fatigue life dropped from 2,511 cycles for the base alloy to 308 cycles for the alloy with $\mathrm{Cu}$ and $\mathrm{W}$ additions.
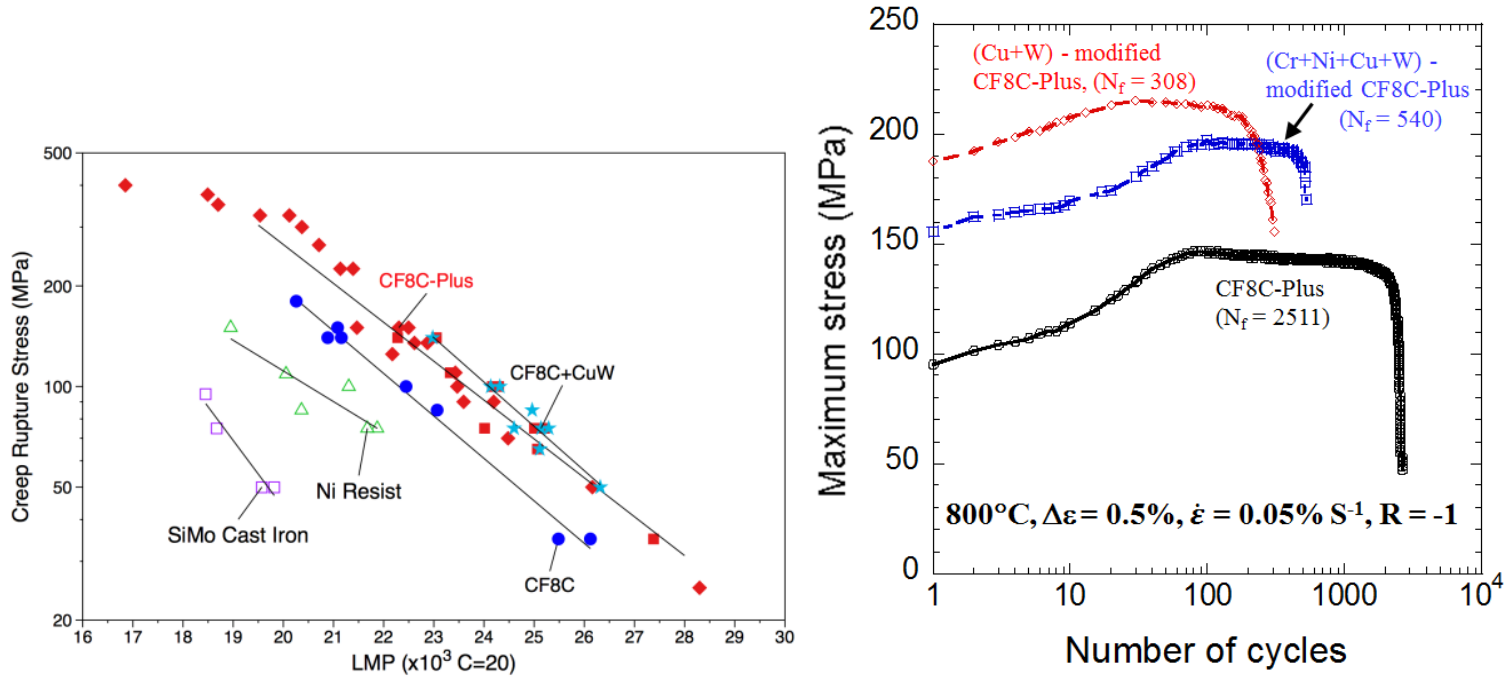

Fig. 11. Comparison of mechanical properties for CF8C-Plus and $\mathrm{Cu} / \mathrm{W}$-modified CF8C-Plus (a) Larson-Miller plot of creep data and (b) variation in maximum stress with number of fatigue cycles with $0.5 \%$ strain.

\subsubsection{Subtask 3. Environmental Effects}

Experiments were conducted in dry (ambient) air, wet air (10\% water vapor), steam and simulated diesel exhaust over a range of temperatures from $550^{\circ}-800^{\circ} \mathrm{C}$. Figure 12 shows the mass change data for $\mathrm{CF} 8 \mathrm{C}, \mathrm{CF} 8 \mathrm{C}$-Plus and $\mathrm{CF} 8 \mathrm{C}+\mathrm{W}, \mathrm{Cu}$ at two different temperatures and three environments. At $650^{\circ} \mathrm{C}$ in laboratory air, the mass gain for $\mathrm{CF} 8 \mathrm{C}$ was slightly lower because of the lower Mn content in 
this alloy. However, with the addition of water vapor, the modified alloys performed better. At $750^{\circ} \mathrm{C}$, the $\mathrm{CF} 8 \mathrm{C}+\mathrm{W}, \mathrm{Cu}$ alloy showed less attack than the other alloys in both wet air and simulated diesel exhaust gas. Thus, there is an advantage to the modifications of CF8C-Plus with $\mathrm{Cu}$ and $\mathrm{W}$ for oxidation resistance in exhaust environments that is important to the applications for exhaust components in diesel engines, and possibly gasoline engines as well.

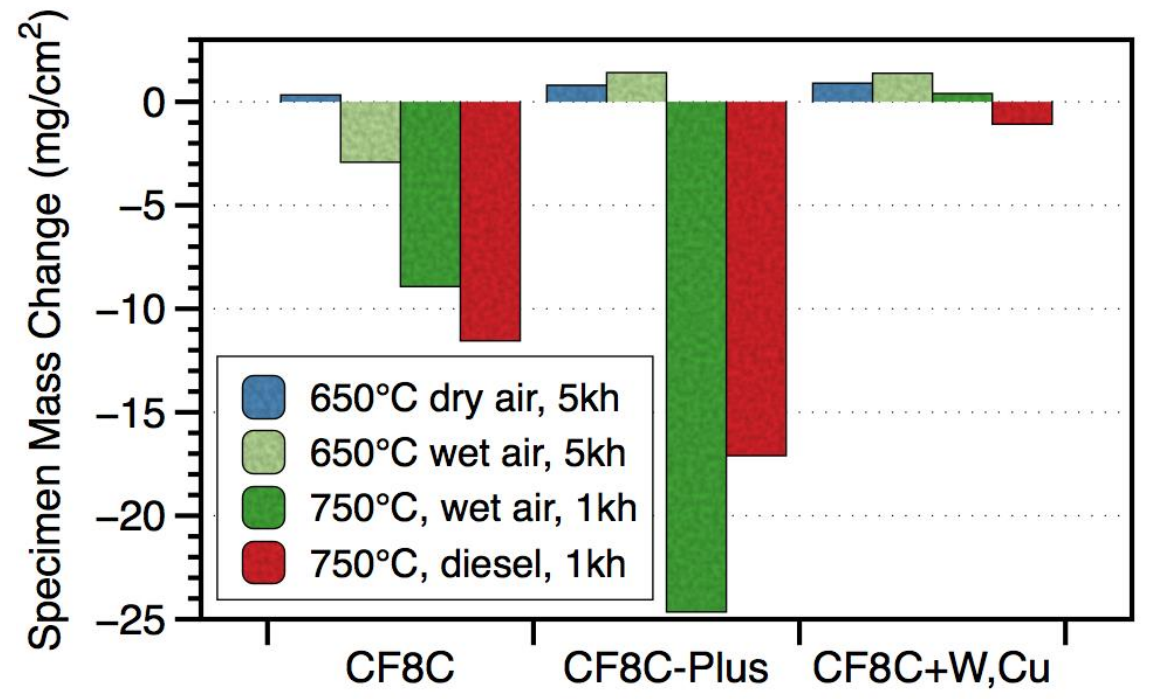

Fig. 12. Mass change data for the base alloy (CF8C) and modified alloys (with and without W and $\mathrm{Cu}$ additions) after exposure in several different conditions.

Specimens exposed for $1 \mathrm{kh}$ have been metallographically sectioned to observe the oxide thickness. Figure 13 shows the performance at the three temperatures. Because of the variation in composition of the cast alloys, there was some variation in oxide thickness. The oxide thicknesses are consistent with the mass change data. At $800^{\circ} \mathrm{C}, \mathrm{CF} 8 \mathrm{C}$-Plus shows a large mass loss due to the formation and spallation of a thick Fe-rich oxide shown in Figure 13c. In laboratory air, a thinner Cr-rich oxide forms with small mass changes. This oxidation problem in the presence of water vapor is typical of stainless steels in this composition range and suggests that an oxidation-resistant coating (Task 5) may be needed.
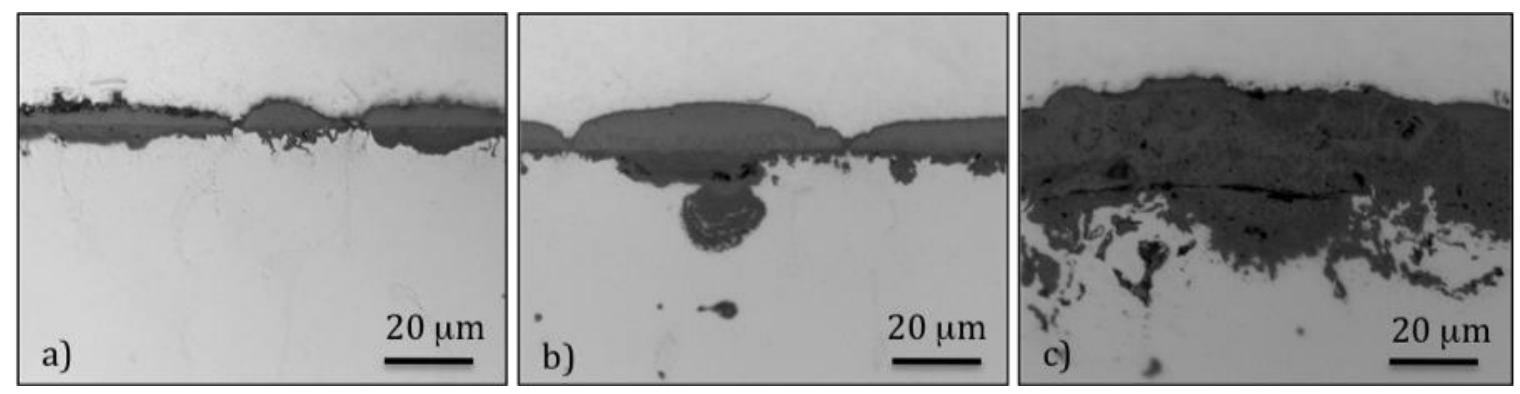

Fig. 13. Light microscopy of polished sections of CF8C-Plus exposed for $1,000 \mathrm{~h}(10,100-\mathrm{h}$ cycles) at (a) $650^{\circ} \mathrm{C}$, (b) $700^{\circ} \mathrm{C}$ and (c) $800^{\circ} \mathrm{C}$.

Comparisons also were made with other cast alloys: NiResist, CF8C, CF10M, HP40Nb and CW6MC, see compositions in Table 1. At $700^{\circ} \mathrm{C}$ in wet air, poor oxidation resistance was observed for CF8C and NiResist with large mass losses. Large initial mass gains followed by stable, slow oxide grow was observed for CF10M and CF8C-Plus. For the higher alloyed HP40Nb and CW6MC, low mass 
changes were observed at $700^{\circ}$ and $750^{\circ} \mathrm{C}$ with a slight mass loss due to volatilization of $\mathrm{Cr}$ oxyhydroxide in this environment.

\subsection{TASK 4. ALLOY DEVELOPMENT AND OPTIMIZATION}

This task investigated further composition changes in CF8C-Plus alloys to optimize performance, particularly improved oxidation resistance at $750^{\circ}-800^{\circ} \mathrm{C}$. The experimental plan was to develop more oxidation resistant compositions while maintaining the exceptional mechanical properties.

Thermodynamic calculations were conducted to explore the potential phase formation effects of changing the $\mathrm{Cr}$ and $\mathrm{Ni}$ contents as well as the $\mathrm{Cu}$ and $\mathrm{W}$ additions. Three compositions were selected for commercial castings with additions of $3 \mathrm{wt} . \% \mathrm{Cu}$ and $1 \mathrm{wt} . \% \mathrm{~W}$ as the base alloy $(\sim 19.5 \% \mathrm{Cr}$, $12.5 \% \mathrm{Ni})$, and two more alloys with additions of more $\mathrm{Cr}$ and $\mathrm{Ni}(21 \mathrm{Cr}-15 \mathrm{Ni}$ and $22 \mathrm{Cr}-17.5 \mathrm{Ni})$ to improve high-temperature oxidation resistance. The addition of $\mathrm{Cu}$ and $\mathrm{W}$ produced a substantial increase in creep life at $750^{\circ} \mathrm{C} 65 \mathrm{MPa}$ from $32 \mathrm{kh}$ for the base alloy to over $45 \mathrm{kh}$ for the $\mathrm{Cu} / \mathrm{W}$ modified composition.

For screening of creep properties, creep testing at $800^{\circ}-850^{\circ} \mathrm{C}$ was used to accelerate the testing. All three $\mathrm{Cu} / \mathrm{W}$ compositions showed longer creep life than the base $\mathrm{CF} 8 \mathrm{C}$-Plus alloy at $850^{\circ} \mathrm{C} / 75 \mathrm{MPa}$ and $800^{\circ} \mathrm{C} / 100 \mathrm{MPa}$ and retain $20-25 \%$ rupture ductility. Figure 14 . However, the alloys with higher $\mathrm{Cr}$ and $\mathrm{Ni}$ contents were not as creep-resistant as the base $\mathrm{Cu} / \mathrm{W}$ alloy. At $800^{\circ} \mathrm{C} / 75 \mathrm{MPa}$, the base CF8C-Plus alloy was similar in creep rupture life to the $\mathrm{Cu} / \mathrm{W}$ modified alloy and higher than the modified alloys with higher $\mathrm{Cr}$ and $\mathrm{Ni}$ contents. Figure 15 shows the $800^{\circ} \mathrm{C}$ mass change data for the same alloys in wet air. Increasing the $\mathrm{Cr}$ content had the expected benefit of increasing the oxidation resistance under these conditions, with $\mathrm{Ni}$ also playing an important supporting role. Comparing Figures 14 and 15, there is a clear tradeoff between the creep- and oxidation-resistance at $800^{\circ} \mathrm{C}$ in the modified alloys, but the modified alloys with enhanced oxidation resistance are still also an improvement over the standard CF8C-Plus in terms of creep-resistance. This represents an important enhancement in properties of the modified CF8C-Plus alloy with $22 \% \mathrm{Cr}$ that represents a significant advantage in comparisons with more expensive cast HK and HP cast alloys and Ni-based superalloys for chemical and petrochemical applications at higher temperatures as well as for gasoline engine turbocharger and exhaust manifold applications. The lower creep strength for HP40Nb is shown in Figure 14. These results also represent an important benefit for any application that demands oxidation resistance and is not suitable to coating applications.

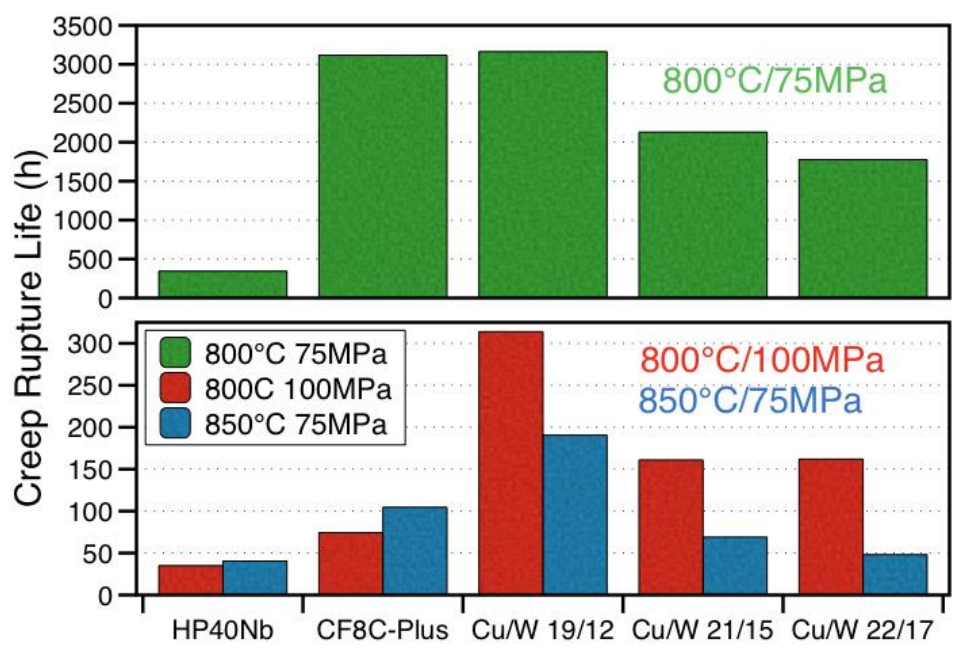

Fig. 14. Creep-rupture life of CF8C-Plus compared to the $\mathrm{Cu} / \mathrm{W}$ enhanced alloys at $8^{\circ}{ }^{\circ} \mathrm{C}-850^{\circ} \mathrm{C}$. 


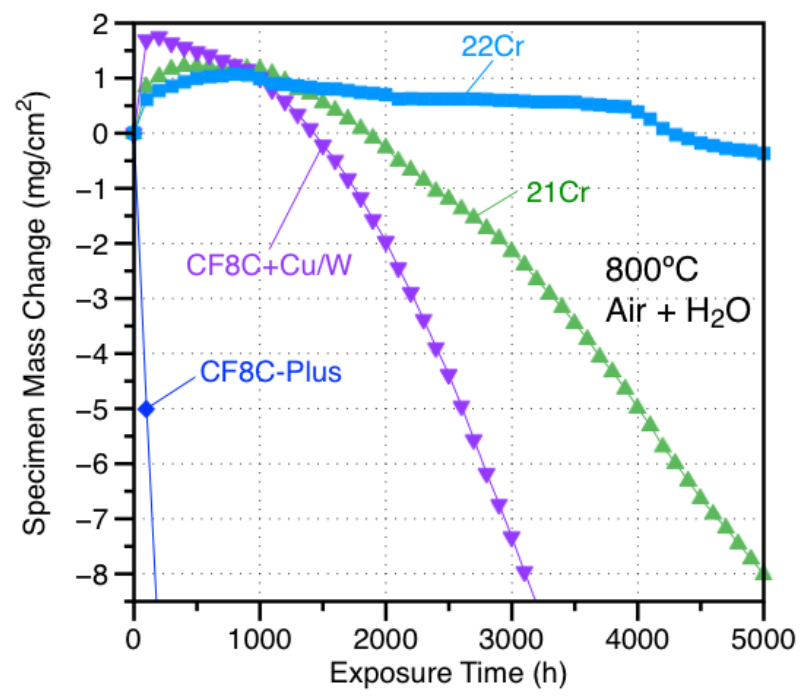

Fig. 15. Specimen mass changes in wet air comparing the CF8C-Plus, to the new alloys $\mathrm{Cu} / \mathrm{W}$ modified $(\mathrm{CF8CW})$ and $\mathrm{Cu} / \mathrm{W}$ modifications with higher $\mathrm{Cr}$ and $\mathrm{Ni}$ contents at $800^{\circ} \mathrm{C}$.

\subsection{TASK 5. COATING EVALUATION}

It is well known that aluminizing $\mathrm{Fe}$ - and $\mathrm{Ni}$-base alloys will improve their high temperature oxidation resistance ${ }^{10,11}$, especially in the presence of water vapor, and this had been explicitly shown for CF8CPlus with laboratory coatings ${ }^{12}$. Figure 16 summarizes some data for coated and uncoated CF8C-Plus. In Figure 16a, the addition of water vapor (found in all combustion environments) caused a severe mass loss for uncoated $\mathrm{CF} 8 \mathrm{C}$-Plus at $800^{\circ} \mathrm{C}$ compared to dry air where the alloy was protective. In contrast, the aluminized specimens all showed low mass changes (note the difference in y-axis between Figs. 16a and 16b) due to the formation of a protective Al-rich oxide on the coating surface. The specific goal of this task was to assess if such coatings would affect the mechanical properties of CF8C-Plus. Coatings were obtained from three sources: (1) ORNL laboratory-scale chemical vapor deposition (CVD) rig, (2) A subcontract with Tennessee Technological University (TTU) to fabricate aluminide coatings by pack cementation, and (3) a commercial slurry coating vendor. Slurry coating is a much lower cost and more commercially likely process for large stainless steel castings.
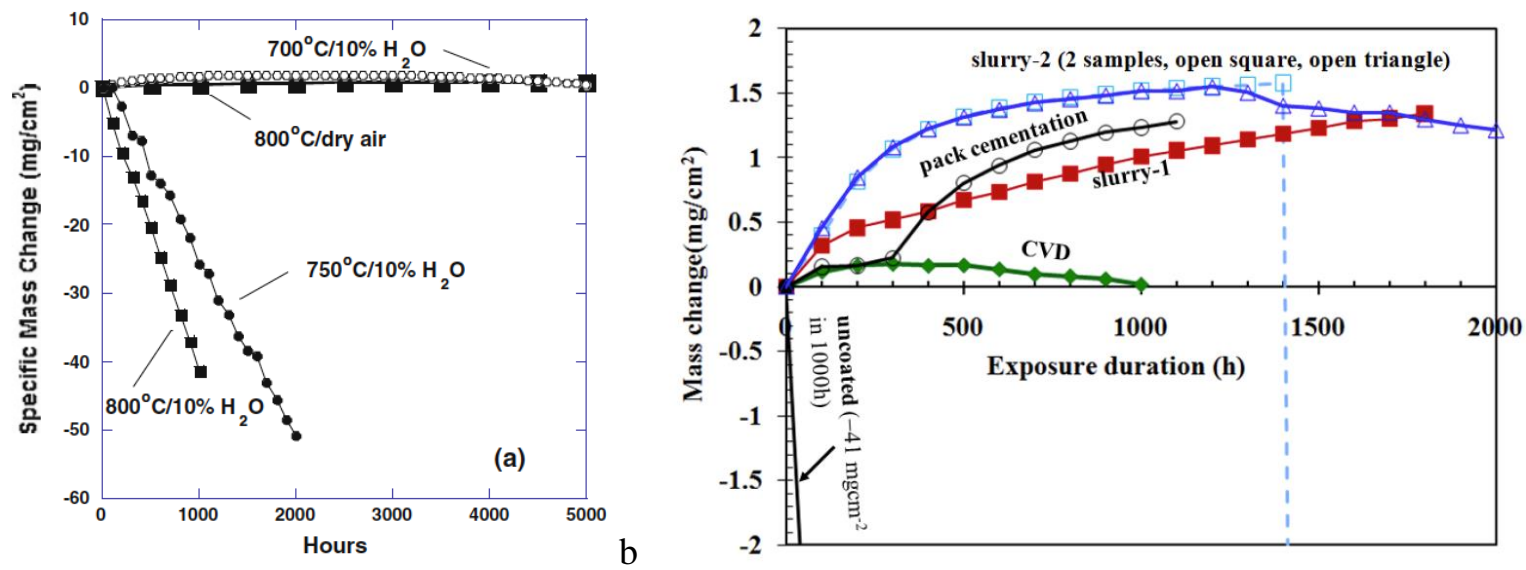

Fig. 16. Specimen mass gain for (a) uncoated and (b) coated CF8C-Plus using several coating methods. 
Figure 17 shows example polished cross sections of CVD and $900^{\circ} \mathrm{C}$ annealed slurry coatings on CF8C-Plus with similar structures and compositions. The $900^{\circ} \mathrm{C}$ anneal reduced the porosity between the inner and Al-rich outer coating layers. One issue with Al-containing coatings is the reaction with $\mathrm{N}$ in the alloy to form AIN (acicular dark particles in Figure 17).
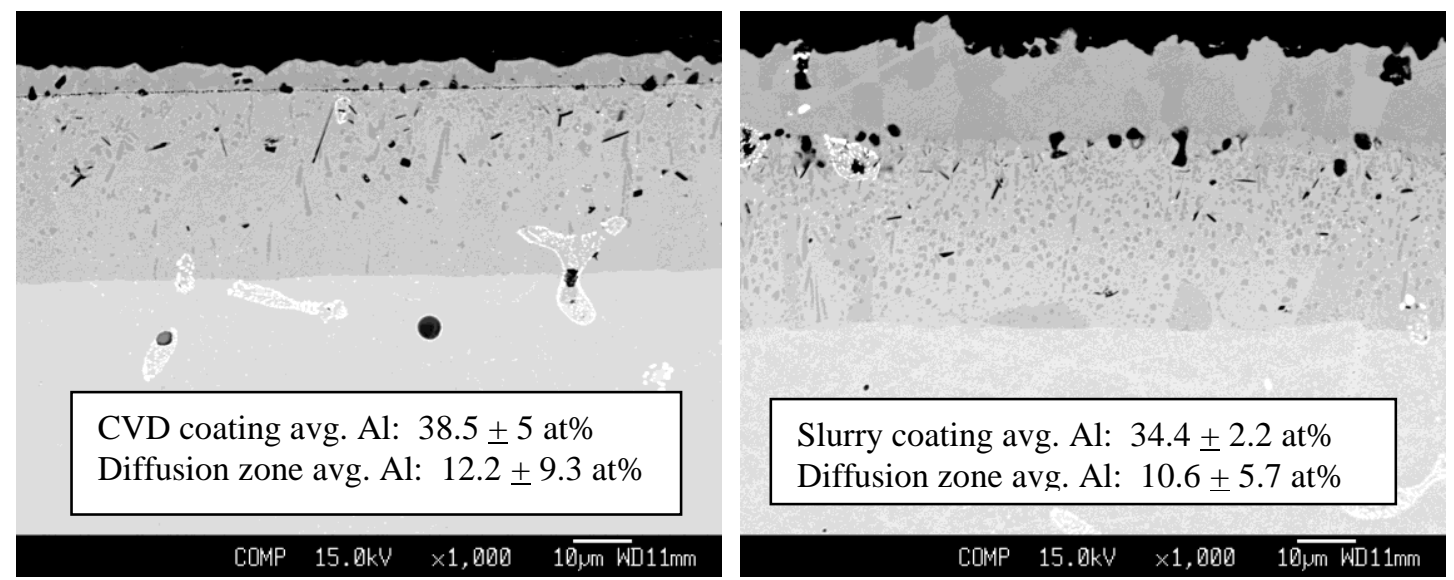

Fig. 17. SEM back-scattered electron images comparing as-fabricated aluminide coatings on CF8C-Plus after $6 \mathrm{~h}$ at $900^{\circ} \mathrm{C}$ : (left) CVD coating and (right) ORNL slurry coating.

To evaluate the effect of the coating on alloy fatigue, full size fatigue specimens were coated. This required considerable coating development at TTU for the pack process. The first pack cementation coated fatigue bar was tested under strain-controlled-condition at $800^{\circ} \mathrm{C}$ with the strain range of $0.5 \%$ in laboratory air. A drop in fatigue life of $14 \%$ was observed and the coated specimen had faster crack initiation and propagation than a similar uncoated specimen.

Figure 18 shows additional fatigue testing conducted at $800^{\circ}$ and $900^{\circ} \mathrm{C}$. Initially, the analysis centered on the effect of the surface coating. However, a second factor became apparent, which is the effect of the heat treatment. Figure 18a shows the difference in maximum stress for coated (blue line) and uncoated (black line) CF8C-Plus. The third specimen (red line) in Figure 18a is an uncoated specimen that was annealed in an inert environment for the same conditions, $30 \mathrm{~min}$ at $900^{\circ} \mathrm{C}$. The maximum stress in both the coated and annealed specimens remained low because neither strain hardened like the as-received material. Both creep and fatigue testing found that annealing at $900^{\circ} \mathrm{C}$ with or without a coating significantly degraded the creep strength of CF8C-Plus, similar to other austenitic alloys. Thus, in Figure $18 \mathrm{~b}$, the coated specimen heat treated at $900^{\circ} \mathrm{C}$ for $30 \mathrm{~min}$ had the longest fatigue lifetime because this material was the weakest. Based on these results, the heat treatment for the commercial slurry coating was $1079^{\circ} \mathrm{C}$ for $4 \mathrm{~h}$ to avoid this creep debit. As can be seen in Figure 18b, the fatigue life for the commercial slurry coating was within $10 \%$ of the uncoated material. A full range of stresses and temperatures is needed to fully study the fatigue behavior of coated CF8C-Plus. Nevertheless, these initial experiments suggest that coating will not significantly reduce the mechanical properties of the alloy provided the heat treatment is conducted at an appropriate temperature (i.e. $>1000^{\circ} \mathrm{C}$ ) to avoid the creep debit observed at $900^{\circ} \mathrm{C}$. 


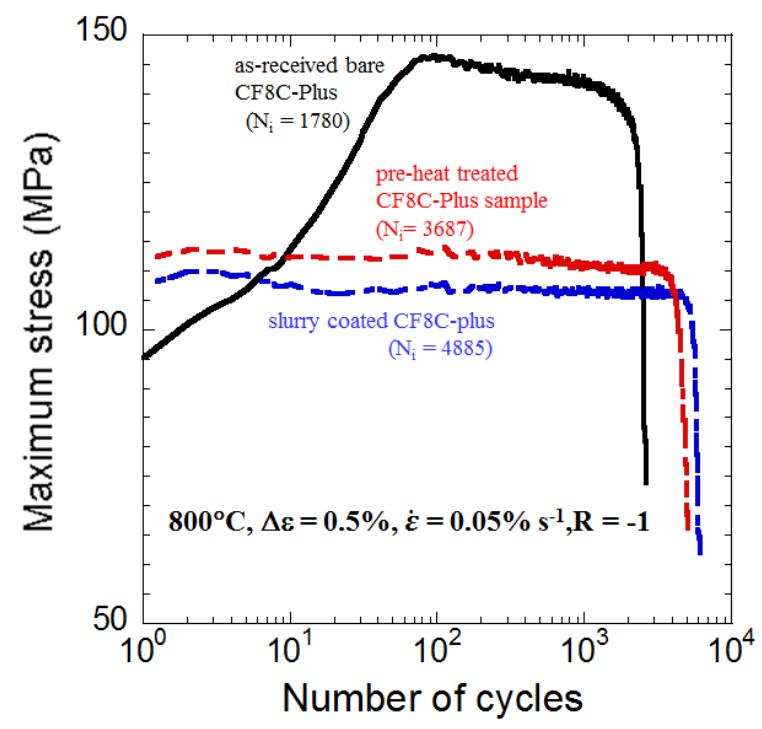

(a)

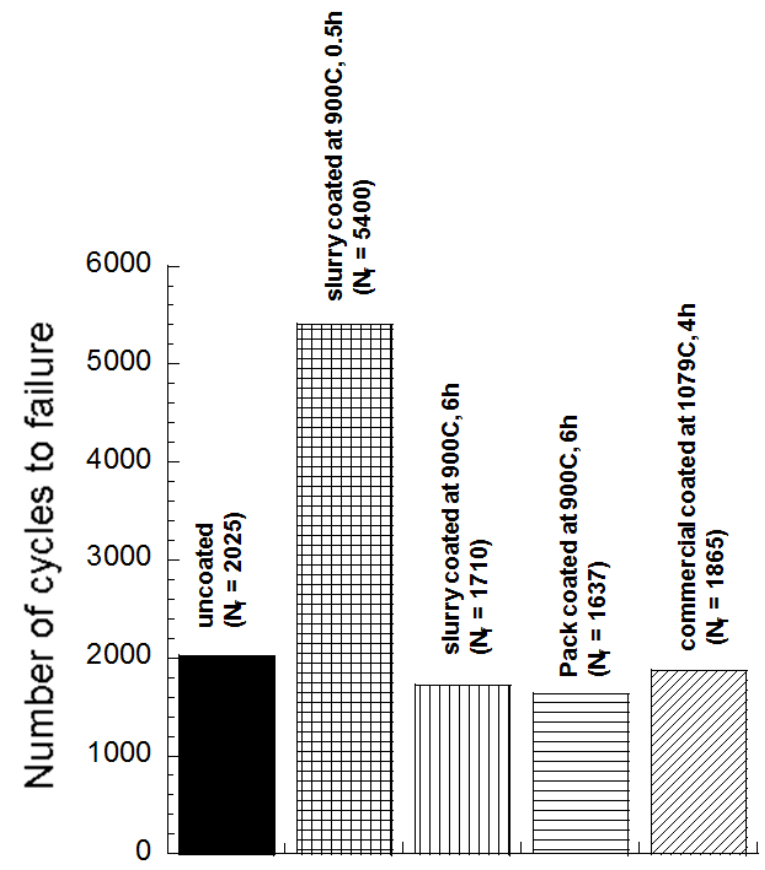

(b)

Fig. 18. (a) Variation in maximum stress with number of fatigue cycles for the bare, annealed $900^{\circ} \mathrm{C} / 0.5 \mathrm{~h}$, and slurry coated (annealed $900^{\circ} \mathrm{C} / 0.5 \mathrm{~h}$ ) $\mathrm{CF8C}$-Plus. $\mathrm{N}_{\mathrm{i}}$ represents the number of cycles required to initiate a macro-crack in the sample. (b) Comparison between the number of fatigue cycles to failure $\left(\mathrm{N}_{\mathrm{f}}\right)$ of uncoated and coated $\mathrm{CF8C}$-Plus specimens at $800^{\circ} \mathrm{C}$ with $0.5 \%$ total strain range and $R=-1$. 


\section{BENEFITS ASSESSMENT}

Significant energy savings and reduced carbon emissions can result from increasing the adoption of CF8C-Plus cast austenitic steels. The potential benefits include the following:

- Increased energy efficiency in fossil energy steam boilers, re-heaters, and turbines

- Increased fuel efficiency for diesel and reciprocating engines at higher engine temperatures

- Lower emissions released from diesel engines

The economic benefit of cast CF8C-Plus steel depends on the application, as well as the materials that it replaces or displaces for such applications. For diesel exhaust systems, the 500 tons of CF8C-Plus steel used by Caterpillar to make the regeneration system burner housing for diesel particular filters had a direct materials value of over $\$ 6$ million, but prevented the use of nickel-based superalloys that would cost $\sim \$ 35$ million for the same application, so the benefit is a savings of $\sim \$ 29$ million. The CF8C-Plus steel exhaust components require no heat-treatments after casting, so there is another $\$ 6$ million cost savings relative to cast irons, steels or alloys that require heat-treating. Energy benefits for automotive and diesel exhaust component applications accrue from diesel engines being 10-15\% more fuel efficient and cleaner (and 15-20\% lower emissions) at higher engine temperatures, while turbogasoline benefits can be $20 \%$ more fuel efficient. Substituting CF8C-Plus for conventional exhaust materials can use 4-5 times less material, which is another energy and cost savings. If CF8C-Plus were used for fossil energy steam boiler/reheater and turbine applications, energy would be saved by higher efficiency. For example, a recently commissioned coal-fired boiler is nearly $40 \%$ efficient HHV, while the U.S. fleet average is $\sim 33 \%$, meaning the plant will burn $>500,000$ fewer tons of coal each year to generate the same amount of electricity. The economic impact of widespread use of CF8C-Plus for chemical/petrochemical, electric power production and transportation exhaust systems could easily be \$2-3 billion, or more.

Estimates of total energy savings for substitution of CF8C-Plus steel were made in 2010 relative to using Ni-based superalloy 625 for automotive turbocharger and exhaust manifold components, and for gas-turbine and steam-turbine casing components. The lifetime energy savings include energy savings to manufacturing parts as well as vehicle use for the automotive market in Fig. 19, whereas they are just for turbine use in Fig.20. The energy savings for automotive grows each year to reach a level of 174 trillion Btu in 2025 (Fig.19). For gas and steam turbines, the total energy use grows more for gas turbine than for steam turbine, and reaches about 62 trillion Btu in 2025 (Fig.20). The combined use of CF8C-Plus steel for these two applications is an energy savings of 236 trillion Btu in 2025. 


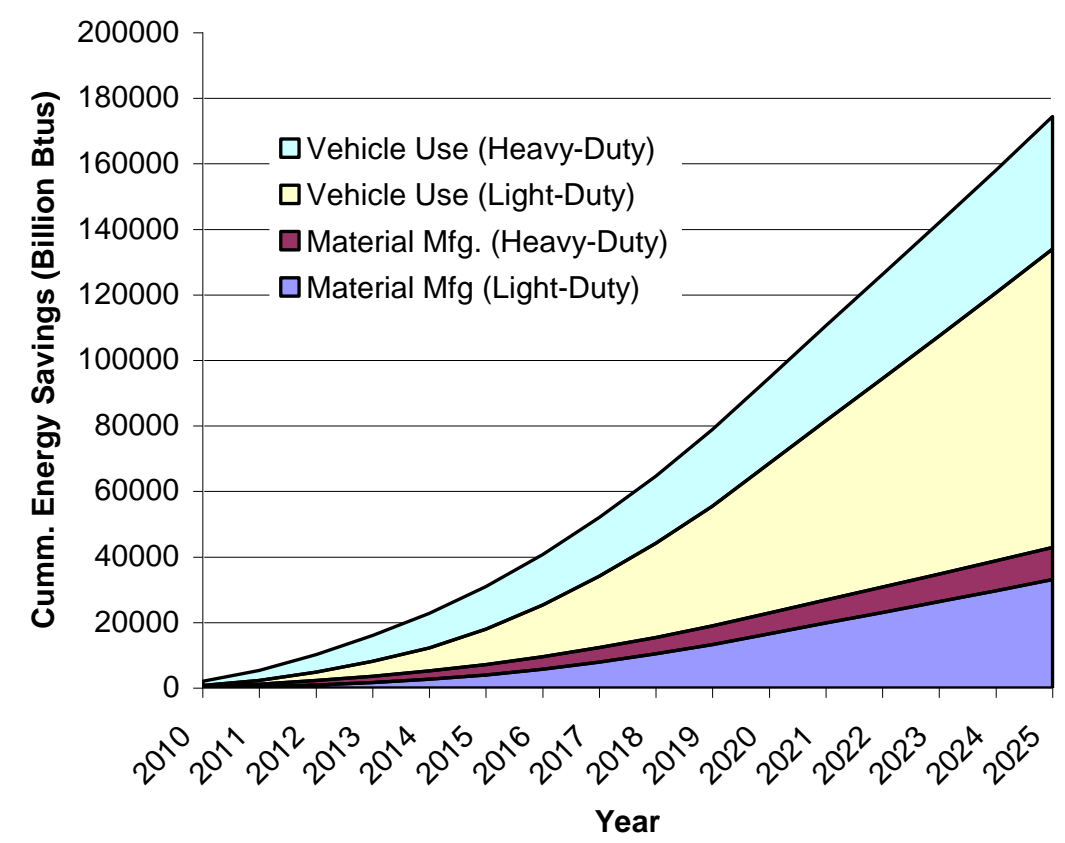

Fig. 19. Estimated total cumulative life energy savings of CF8C-Plus in the automotive market

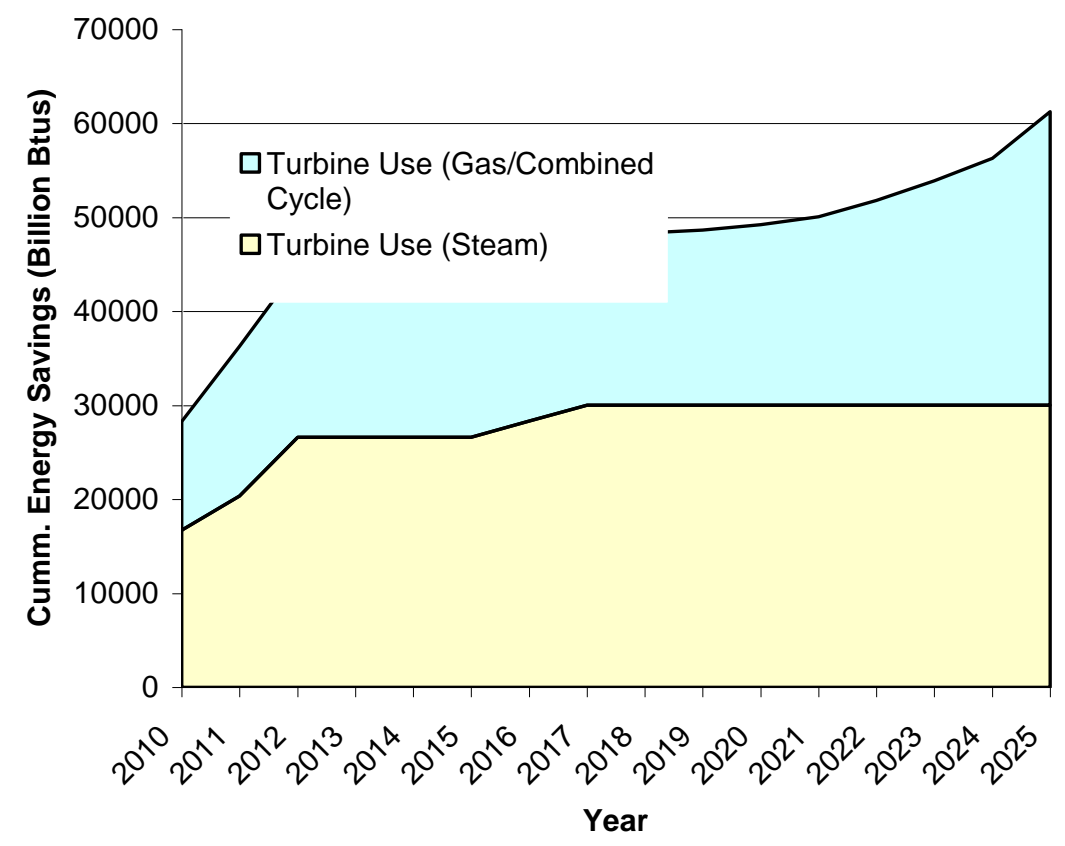

Fig. 20. Estimated cumulative material use energy savings due to CF8C-Plus use in the turbine market. 


\section{COMMERCIALIZATION}

Oak Ridge National Laboratory and Caterpillar jointly hold the patent for CF8C-Plus. Trial and commercial licenses are available to interested casting companies and end-users by either company. Currently, Stainless Foundry \& Engineering (SF\&E) in Milwaukee, WI has a commercial license for casting CF8C-Plus, and has produced the keel bars for this project as well as keel bars for the Honeywell study of CF8C-Plus for turbocharger housings (Honeywell decided not to participate in this deployment project.) SF\&E has the capability of producing sand cast or investment cast exhaust components of CF8C-Plus for turbocharger or exhaust manifold applications in diesel or gasoline engines. SF\&E in the past produced prototype CF8C-Plus exhaust components for Waukesha Engine, Dresser natural gas reciprocating engines that were field-tested and found to work well.

The Solar Turbines, Inc. commercial demonstration of a CF8C-Plus turbine housing in a 4.6MW Mercury 50 engine was sited at an expansion of a CHP installation at the U.S. Marine Corp. Base in 29 Palms, California. Commercial operation of this facility is expected to begin in October 2013 after unexpected delays. The housing will be monitored during field service and inspected after 90 days of operation followed by indefinite continued operation. Hopefully, this demonstration and associated data collection will enable future turbine designs and other turbine manufacturers to take full advantage of the excellent properties of CF8C-Plus. The defect-free air-melt casting of CF8C-Plus steel demonstrated the excellent castability (and metal fluidity) of this alloy. General Electric has taken a trial license in the past to test CF8C-Plus for gas turbine component applications, and Siemens has also done testing in the past for gas turbine casing applications. Rolls Royce has also expressed interest in CF8C-Plus, so gas turbine applications are a potentially large market for CF8C-Plus.

Honeywell Turbo Technologies is currently pursuing testing and evaluation of CF8C-Plus steel for the cast turbocharger housing application, as upgrades to SiMo and Ni-resist cast irons, or more cost effective substitutes for HK or HP type alloys. Turbocharger applications include diesel and natural gas reciprocating engine, and the recent proliferation of turbochargers in gasoline engine light truck and passenger vehicle markets. The castability, and fatigue and thermal fatigue resistance of CF8CPlus also makes this material desirable for exhaust manifold applications, particularly when matched with CF8C-Plus turbochargers. The oxidation resistance of the modified CF8C-Plus with Cu and W and higher $\mathrm{Cr}$ levels would definitely be an advantage for gasoline engine applications. The successful application of slurry aluminized coatings (investigated in this project) may also be applicable to the turbocharger and exhaust manifold applications, depending on the cost. Cummins is currently exploring the use of CF8C-Plus steel for diesel engine exhaust manifold applications.

Duraloy produced a centrifugally cast pipe for this project, and in the past, MetalTek International obtained a trial license for CF8C-Plus and produced tons of centrifugally cast pipes for a Shell application, and successfully welded those pipes together. There is great potential for use of CF8CPlus steel in the chemical and petrochemical industries based on its large improvement in creepresistance over $\mathrm{CF} 8 \mathrm{C}, 347 \mathrm{H}, \mathrm{CF} 10 \mathrm{M}$, and $316 \mathrm{H}$, and its comparable or slightly better creep-resistance than $800 \mathrm{H}$, HK and HP type cast alloys. The ability to slurry aluminize CF8C-Plus would present outstanding resistance to oxidation, sulfidation and carburization that would be very beneficial to these applications

The outstanding creep-resistance of cast CF8C-Plus steel and its advantage over $347 \mathrm{H}$ and super $304 \mathrm{H}$ steels and comparability to solid solution Ni-based superalloys 625 and 617 has prompted the Electric Power Research Institute (EPRI) to look at the properties of wrought (hot-extruded) CF8C-Plus steel 
for main steam line piping in advanced fossil power plants. To this end, they have encouraged Carpenter Technologies and Wyman Gordon (a PCC Company) to take trial licenses for CF8C-Plus from Caterpillar in 2009-2011. This application looks very promising.

For applications requiring ASME code qualification, such as valves and pump components in a coalfired power plant, completion of the code case is a prerequisite for the adoption of CF8C-Plus for these applications. In order to support code qualification of the wrought version of CF8C-Plus, EPRI wrote a letter in July 2012 encouraging completion of the CF8C-Plus code case and the code case progress has been monitored by Babcock \& Wilcox. The creep testing and weld evaluations needed to complete the code case has transitioned over to Office of Fossil Energy funding and is currently approximately $35 \%$ complete. With 24 creep frames now operating, it is expected that the creep data package will be completed in 2015 for submission to the code committee.

In summary for the work on CF8C-Plus, the properties and efforts generated by this project have gone a long way in creating new opportunities and supporting existing opportunities to expand commercialization of CF8C-Plus for a wide range of applications.

Regarding the other alloys investigated in this study, Table 2 lists the $\mathrm{Cu} / \mathrm{W}$ modified alloys and their current status compared to CF8C-Plus. The alloy with $\mathrm{Cu} / \mathrm{W}$ additions has higher creep strength at a modest increase in alloy cost. It is likely that applications interested CF8C-Plus may also consider the $\mathrm{Cu} / \mathrm{W}$ version in the future because of its higher strength. The modified versions of the $\mathrm{Cu} / \mathrm{W}$ composition with higher $\mathrm{Cr}$ and $\mathrm{Ni}$ were selected to improve the oxidation resistance of this alloy. Both showed improvement in oxidation resistance and some decrease in creep resistance. The higher $\mathrm{Ni}$ contents will increase the cost of these alloys relative to the $19 \mathrm{Cr}-12 \mathrm{Ni}$ in the base alloy.

Table 2. Summary of status of alloys evaluated in this work

\begin{tabular}{|l|c|l|}
\hline Alloy & Commercial heats & Current status \\
\hline CF8C-Plus & Many & $\begin{array}{l}\text { Commercially adopted; this project successfully } \\
\text { deployed alloy into 4.6MW turbine housing application } \\
\text { with industrial partner; ASME code case in progress to } \\
\text { be completed in 2015 }\end{array}$ \\
\hline CF8C-Plus+Cu/W & 5 & $\begin{array}{l}\text { Higher creep strength version; this project expanded } \\
\text { the available fatigue and oxidation data available on this } \\
\text { alloy; commercial interest not yet established. }\end{array}$ \\
\hline Mod. $\mathrm{Cu} / \mathrm{W} 21 \mathrm{Cr}-15 \mathrm{Ni}$ & 1 & $\begin{array}{l}\text { Initial creep and oxidation data generated; improved } \\
\text { oxidation resistance achieved with higher Cr and Ni } \\
\text { contents, but lower creep strength observed. }\end{array}$ \\
\hline Mod. $\mathrm{Cu} / \mathrm{W} 22 \mathrm{Cr}-17 \mathrm{Ni}$ & 1 & $\begin{array}{l}\text { Initial creep and oxidation data generated; further } \\
\text { improvement in oxidation resistance and only minor } \\
\text { additional drop in creep strength; most likely alloy } \\
\text { composition for further development for petrochemical } \\
\text { or other corrosive environment applications. }\end{array}$ \\
\hline
\end{tabular}




\section{ACCOMPLISHMENTS}

The project was broken down into five tasks:

Task 1: Commercial Demonstration

- An industrial demonstration proposal from Solar Turbines Inc. for cost shared R\&D for CF8CPlus as a turbine combustor housing was selected.

- The Mercury 50 turbine with a CF8C-Plus housing was delivered to the construction site at the U.S. Marine Corp Base at 29 Palms, California.

Task 2: ASME Boiler and Pressure Vessel Code Case

- 24 creep frames were refurbished for testing, an asset that will assist in code case testing for other materials

- A tensile data set was completed for the time-independent portion of the CF8C-Plus code case and was presented to the ASME committee in May 2012.

- CF8C-Plus was added to ASTM specifications A297/A297M-10 and A488/A488M-10 and ballots are being prepared for A743/A743M-12 and A351/A351M-12b.

- Additional funds were obtained from the ORNL Technology Maturation Fund to keep the creep testing in progress in 2013 and additional funds will be obtained from the DOE Office of Fossil Energy to complete the work and analyze the data.

Task 3: Property Database Development

- Cross-weld creep testing was completed showing no debit in creep life for CF8C-Plus.

- Fatigue testing was completed at $600^{\circ}-900^{\circ} \mathrm{C}$ on CF8C-Plus and comparison with the W/Cu modified CF8C-Plus showed that the higher creep strength in the modified alloy reduced the fatigue life.

- The comparison of the environmental resistance of CF8C-Plus and CF8C-Plus modified with W and $\mathrm{Cu}$ was completed showing enhanced oxidation resistance of the alloy with $\mathrm{W}$ and $\mathrm{Cu}$.

- The environmental testing at $750^{\circ}-800^{\circ} \mathrm{C}$ confirmed that the $\mathrm{Mn}$ and $\mathrm{N}$ additions that improve creep strength do not significantly improve oxidation resistance, thus the need for a protective coating.

Task 4: Alloy development and optimization

- $\quad$ Two new alloy compositions with higher $\mathrm{Cr}$ and $\mathrm{Ni}$ contents and the same $\mathrm{Cu}$ and $\mathrm{W}$ additions were selected based on thermodynamic computational work and were commercially cast and evaluated.

- The $\mathrm{Cu}$ and $\mathrm{W}$ addition increased the $800^{\circ} \mathrm{C}$ creep life but increasing the $\mathrm{Cr}$ and $\mathrm{Ni}$ contents decreased this benefit compared to the base alloy composition.

- The higher $\mathrm{Cr}$ and $\mathrm{Ni}$ contents increased the oxidation resistance at $800^{\circ} \mathrm{C}$ in wet air out to $5,000 \mathrm{~h}$ of exposure.

Task 5: Coating evaluation

- Laboratory and commercial Al-rich coatings were shown to improve oxidation resistance at $800^{\circ} \mathrm{C}$ in wet air, a condition where the uncoated CF8C-Plus has excellent creep strength but poor oxidation resistance.

- A slurry coating process was developed that produced a coating with a similar structure and composition as the more expensive chemical vapor deposition process.

- The coating task demonstrated several coating options that greatly improved the oxidation resistance of CF8C-Plus without a significant reduction in the low cycle fatigue behavior at $800^{\circ}$ and 
$900^{\circ} \mathrm{C}$. The heat treatment of the coating was found to be critical in maintaining the mechanical properties of the substrate.

\subsection{PUBLICATIONS AND PRESENTATIONS}

- B. A. Pint, "Deployment of New High-Temperature Alloys for Power Generation Systems," invited presentation at TMS Annual Meeting, Seattle, WA, February, 2010.

- B. A. Pint, "Deployment of New High-Temperature Alloys for Power Generation Systems," presentation at NACE Corrosion 2010, San Antonio, TX, March, 2010.

- P. J. Maziasz and B. A. Pint, (2010) "High Temperature Performance of Cast CF8C-Plus Austenitic Stainless Steel," ASME Paper \#GT2010-23006, presented at the International Gas Turbine \& Aeroengine Congress \& Exhibition, Glasgow, Scotland, June, 14-18, 2010.

- D. Kumar, "Low cycle fatigue behavior of alloy CF8C-Plus between 600 to $900^{\circ} \mathrm{C}$," presentation at the Material Science and Technology 2010 (MS\&T2010) conference held in Houston, TX in October 2010.

- D. Kumar, "Effect of coating on the low-cycle-fatigue behavior of CF8C-Plus at $800^{\circ} \mathrm{C}$," presentation at the Material Science and Technology 2010 (MS\&T2010) conference held in Houston, TX in October 2010.

- P. J. Maziasz and B. A. Pint, (2011) "High Temperature Performance of Cast CF8C-Plus Austenitic Stainless Steel," Journal of Engineering for Gas Turbines and Power, v.133 (10), Art. No. 092102

- $\quad$ D. Kumar, S. Dryepondt, E, Lara-Curzio, B. A. Pint, J. A. Haynes and B. L. Armstrong, (2011)

"Performance of Aluminide Coatings Applied on Alloy CF8C-Plus at 800 C," NACE Paper 11-197, Houston, TX, presented at NACE Corrosion 2011, Houston, TX, March 2011.

- D. Kumar, "Low-cycle-fatigue behavior of coated and uncoated CF8C-Plus between $600^{\circ} \mathrm{C}$ and $800^{\circ} \mathrm{C}$," Presentation made at the TMS Annual Meeting, February 2011 in San Diego, CA.

- J. A. Haynes, "Oxidation Behavior of Slurry Aluminide Coatings on Stainless Steel Alloy" presentation at the International Conference on Metallic Coatings and Thin Films in San Diego, CA in May 2011.

- J. A. Haynes, B. L. Armstrong, S. N. Dryepondt and Y. Zhang, "Oxidation of Slurry Aluminide Coatings on Cast Stainless Steel Alloy CF8C-Plus at 800C in Water Vapor," Oxidation of Metals (2013) in press.

- $\quad$ S. Dryepondt, B. A. Pint and P. J. Maziasz, "New creep resistant, cast alloys with improved oxidation resistance in water vapor at $650^{\circ}-800^{\circ} \mathrm{C}$, submitted to Oxidation of Metals.

- $\quad$ K. A. Unocic, S. Dryepondt and P. J. Maziasz, "Effect of Cr and Ni contents on the creep and oxidation behavior of W/Cu modified cast austenitic steel," submitted to Materials Science and Engineering. 


\section{CONCLUSIONS}

A deployment project was initiated for a new cast austenitic stainless steel, CF8C-Plus, which was jointly developed by Caterpillar and ORNL. Five tasks were defined:

- Partnering with Solar Turbines, Inc., a turbine housing for a 4.6MW gas turbine was fabricated and deployed at a U.S. Marine Corp. base in California (see Figures 3 and 4). Initial operation is expected to begin in October 2013.

- An ASME Boiler and Pressure Vessel code case was initiated for CF8C-Plus, tensile data package collection was completed (Figure 6) and 35\% of the creep data needed for the code case was completed (Figure 7). CF8C-Plus has been added to a number of relevant ASTM specifications. Completion of the code case for operation to $816^{\circ} \mathrm{C}$ is expected in 2015 with funding from the DOE Office of Fossil Energy. The three commercial batches of CF8C-Plus showed higher creep strength than previous data (see Figure 7), however, this extended the time necessary to complete the data collection. Twenty-four creep frames are now collecting data for this effort, greatly speeding data collection from the original 9 frames commissioned in 2010. Preparation of the frames and conducting $\sim 170,000 \mathrm{~h}$ of creep testing on three commercial heats of CF8C-Plus represented one third of the funding of this project and approximately $2 / 3$ of the anticipated funds necessary to complete the code case.

- An expanded database was developed for CF8C-Plus and Cu/W-modified CF8C-Plus including additional cross-weld creep data, fatigue data at $600^{\circ}-900^{\circ} \mathrm{C}$ and environmental resistance data at $650^{\circ}-800^{\circ} \mathrm{C}$, see section 3.3. The weld data for CF8C-Plus showed no debit for the weld. The oxidation results at $750^{\circ}-800^{\circ} \mathrm{C}$ confirmed that an oxidation resistant coating is needed at these temperatures for CF8C-Plus, especially in the presence of water vapor, such as diesel exhaust.

- New alloy compositions were investigated with higher $\mathrm{Cr}$ and $\mathrm{Ni}$ contents to improve the high temperature oxidation resistance. Compared to the base alloy with $\mathrm{Cu}$ and $\mathrm{W}$, increasing the $\mathrm{Cr}$ and $\mathrm{Ni}$ contents did improve oxidation resistance by a factor of more than 10 but reduced the high temperature creep strength compared to the baseline alloy with $\mathrm{Cu} / \mathrm{W}$, Figure 14 and 15 . Compared to CF8C-Plus (no $\mathrm{Cu}$ and $\mathrm{W}$ additions), the new alloys showed higher creep strength in some conditions and may be further developed for applications where corrosion resistance is critical.

- The performance of laboratory and commercial aluminide coatings was evaluated in oxidation testing at $800^{\circ} \mathrm{C}$ and fatigue testing at $800^{\circ} \mathrm{C}$. Figures 16-18. Significant improvements in oxidation resistance could be attained without reducing the low cycle fatigue life. One important finding was that the coating heat treatment was very critical for both properties and heat treatments of $>1000^{\circ} \mathrm{C}$ were needed to retain the high creep strength of CF8C-Plus. 


\section{RECOMMENDATIONS}

1. Complete the ASME BPV code case on CF8C-Plus.

2. Continue to pursue new applications for this alloy, including turbocharger housings and especially other applications where Ni-base alloys could be replaced with a substantial $(\sim 5 \mathrm{X})$ cost savings for similar properties.

3. Continue the commercialization process for the $\mathrm{Cu} / \mathrm{W}$-modified version of $\mathrm{CF} 8 \mathrm{C}$-Plus.

4. If an application is identified for $>700^{\circ} \mathrm{C}$, continue to develop oxidation resistant coatings for $\mathrm{CF} 8 \mathrm{C}$-Plus or the higher alloyed versions of $\mathrm{Cu} / \mathrm{W}$-modified $\mathrm{CF} 8 \mathrm{C}$-Plus. 


\section{REFERENCES}

1. P. J. Maziasz, and M. P. Pollard, "High-Temperature Cast Stainless Steel," Advanced Materials \& Processes, Vol.161 (10), pp.57-59 (2003).

2. P. J. Maziasz, J. P. Shingledecker, N. D. Evans, and M. P. Pollard, "New Heat-Resistant Cast Stainless Steel - CF8C-Plus," Advanced Materials \& Processes, Vol.166 (10), pp.27-29 (2008).

3. P. J. Maziasz, J. P. Shingledecker, N. D. Evans, and M. P. Pollard, "Developing New Cast Austenitic Stainless Steels with Improved High-Temperature Creep Resistance," Journal of Pressure Vessel Technology, Vol.131 (5), pp.051404(1-7) (2009).

4. P. J. Maziasz, T. McGreevy, M. J. Pollard, C. W. Siebenaler, and R. W. Swindeman, "Heat and Corrosion Resistant Cast CF8C Stainless Steel With Improved High Temperature Strength and Ductility," U.S. Patent 7,153,373 B2, Dec. 26, 2006.

5. J. P. Shingledecker, P. J. Maziasz, N. D. Evans, M. L. Santella and M. P. Pollard, "CF8C Plus, A New High Temperature Austenitic Casting Alloy for Advanced Power Systems," Energy Materials, Vol.1 (1), pp. 25-32 (2006).

6. J. P. Shingledecker, P. J. Maziasz, N. D. Evans and M. P. Pollard, "Creep Behavior of a New Cast Austenitic Alloy," International Journal of Pressure Vessels and Piping, Vol.84, pp.2128 (2007).

7. P. J. Maziasz, J. P. Shingledecker, N. D. Evans, and M. P. Pollard, "Developing New Cast Austenitic Stainless Steels With Improved High-Temperature Creep Resistance," Paper CREEP2007-26840, Proc. CREEP8 - 8th International. Conf. on Creep and Fatigue at Elevated Temperatures, ASME-PVP2007, New York, NY (2007).

8. J. P. Shingledecker, P. J. Maziasz, N. D. Evans and M. P. Pollard, "Alloy Additions for Improved Creep-Rupture Properties of a Cast Austenitic Alloy," in Creep Deformation and Fracture, Design and Life Extension, eds. R.S. Mishra, J.C. Earthman, S.V. Raj, and R. Viswanathan, Materials Science \& Technology 2005, TMS, Warrendale, PA, pp. 129-138 (2005).

9. D. Gandy, J.P. Shingledecker, P.J. Maziasz, G. Mauer, and J. Magee, "Mechanical Properties and Microstructure of a Wrought Austenitic Stainless Steel for Advanced Fossil Power Plant Applications," Proc. of the Sixth International Conference on Advances in Materials Technology for Fossil Power Plants, ASM-International, Materials Park, OH (2011) pp. 916932.

10. N. V. Bangaru and R. C. Krutenat, "Diffusion Coatings of Steels - Formation Mechanism and Microstructure of Aluminized Heat Resistant Stainless Steels," Journal of Vacuum Science and Technology B Vol.2, pp.806-815 (1984).

11. B. A. Pint and Y. Zhang, "Performance of Al-rich Oxidation Resistant Coatings for Fe-Base Alloys," Materials and Corrosion, Vol.62, pp.549-560 (2011).

12. P. J. Maziasz and B. A. Pint, "High Temperature Performance of Cast CF8C-Plus Austenitic Stainless Steel," Journal of Engineering for Gas Turbines and Power, Vol.133 (10), Art. No. 092102 (2011). 